\title{
An ocean-ice coupled response during the last glacial: a view from a marine isotopic stage 3 record south of the Faeroe Shetland Gateway
}

\author{
J. Zumaque ${ }^{1, *}$, F. Eynaud ${ }^{1}$, S. Zaragosi ${ }^{1}$, F. Marret $^{2}$, K. M. Matsuzaki ${ }^{1}{ }^{\text {*** }}$, C. Kissel $^{3}$, D. M. Roche ${ }^{3,4}$, B. Malaizé ${ }^{1}$, \\ E. Michel $^{3}$, I. Billy ${ }^{1}$, T. Richter ${ }^{5}$, and E. Palis ${ }^{1}$ \\ ${ }^{1}$ EPOC - Environnements et Paléoenvironnements Océaniques, UMR5805, Université Bordeaux I, Talence, France \\ ${ }^{2}$ School of Environmental Sciences, University of Liverpool, Liverpool, L69 7ZT, UK \\ ${ }^{3}$ Laboratoire des Sciences du Climat et de l'Environnement (LSCE), CEA/CNRS-INSU/UVSQ - UMR8212, \\ $91191 \mathrm{Gif}$ s/s Yvette, France \\ ${ }^{4}$ Vrije Universiteit Amsterdam, de Boelelaan 1085, 1081 HV Amsterdam, The Netherlands \\ ${ }^{5}$ NIOZ Royal Netherlands Institute for Sea Research, P.O. Box 59, 1790 AB Den Burg (Texel), The Netherlands \\ * present address: GEOTOP, Montréal, Canada \\ *** present address: Institute of Geology and Paleontology, Graduate School of Science, Tohoku University, Aramaki 6-3, \\ Sendai, 980-8578, Japan
}

Correspondence to: F. Eynaud (f.eynaud@epoc.u-bordeaux1.fr)

Received: 17 July 2012 - Published in Clim. Past Discuss.: 1 August 2012

Revised: 5 November 2012 - Accepted: 14 November 2012 - Published: 7 December 2012

\begin{abstract}
The rapid climatic variability characterising the Marine Isotopic Stage (MIS) 3 ( 60-30 cal ka BP) provides key issues to understand the atmosphere-ocean-cryosphere dynamics. Here we investigate the response of sea-surface paleoenvironments to the MIS3 climatic variability through the study of a high resolution oceanic sedimentological archive (core MD99-2281, 60 21 $1^{\prime} \mathrm{N}$; 09 $27^{\prime} \mathrm{W}$; $1197 \mathrm{~m}$ water depth), retrieved during the MD114-IMAGES (International Marine Global Change Study) cruise from the southern part of the Faeroe Bank. This sector was under the proximal influence of European ice sheets (Fennoscandian Ice Sheet to the East, British Irish Ice Sheet to the South) during the last glacial and thus probably responded to the MIS3 pulsed climatic changes.

We conducted a multi-proxy analysis of core MD992281 , including magnetic properties, x-ray fluorescence measurements, characterisation of the coarse $(>150 \mu \mathrm{m})$ lithic fraction (grain concentration) and the analysis of selected biogenic proxies (assemblages and stable isotope ratio of calcareous planktonic foraminifera, dinoflagellate cyst - e.g. dinocyst - assemblages). Results presented here are focussed on the dinocyst response, this proxy providing the reconstruction of past sea-surface hydrological conditions, qualitatively as well as quantitatively (e.g. transfer function
\end{abstract}

sensu lato). Our study documents a very coherent and sensitive oceanic response to the MIS3 rapid climatic variability: strong fluctuations, matching those of stadial/interstadial climatic oscillations as depicted by Greenland ice cores, are recorded in the MD99-2281 archive. Proxies of terrigeneous and detritical material suggest increases in continental advection during Greenland Stadials (including Heinrich events), the latter corresponding also to southward migrations of polar waters. At the opposite, milder sea-surface conditions seem to develop during Greenland Interstadials. After $30 \mathrm{ka}$, reconstructed paleohydrological conditions evidence strong shifts in SST: this increasing variability seems consistent with the hypothesised coalescence of the British and Fennoscandian ice sheets at that time, which could have directly influenced sea-surface environments in the vicinity of core MD99-2281.

\section{Introduction}

The alternation of glacial/interglacial periods that defines the Quaternary is thought to be mainly triggered by changes in orbital parameters (e.g. Imbrie et al., 1993; Berger, 2006). However, a higher frequency in climatic variability is 
detected during glacial periods and appears to have no direct orbital forcing origin. This millennial-scale climatic variability was observed for the first time in the oxygen isotope records from Greenland ice cores (Dansgaard et al., 1993) and is expressed through significant and rapid changes in atmospheric temperatures, especially during the Marine Isotope Stage (MIS) 3 (e.g. Dansgaard et al., 1993; Kiefer et al., 2002; Wolff et al., 2010; Austin and Hibbert, 2012). These oscillations switching between warm (GIs for Greenland interstadials) and cold (GSs for Greenland Stadials) climatic phases are known as the Dansgaard-Oeschger (DO) cycles (e.g. Bond et al., 1993; Dansgaard et al., 1993). These cycles are punctuated by abrupt ice-sheet discharge events, the so-called Heinrich Events (HEs), corresponding to some of the DO coldest phases, and are illustrated in the North Atlantic sediments by layers rich in silico-clastic coarse particles (ice-rafted debris - IRD; e.g. Bond et al., 1992). IRD are transported by floating ice and preferentially deposited in the Ruddiman Belt (Ruddiman, 1977), a latitudinal belt $\left(40\right.$ to $50^{\circ} \mathrm{N}$ ) identified as the preferential area of melting for icebergs during these discharge periods. Study of these IRD particles allowed the characterisation of sources involved in these events with great influence of the Laurentide ice sheet during HE1, HE2, HE4 and HE5, and a greater influence of European ice sheets during HE3 and HE6 (cf. Hemming, 2004 and references therein). At the same time, the North Atlantic basin recorded large changes in hydrological conditions, corresponding to temperature and salinity decreases in sea-surface waters and changes in the meridional overturning circulation (MOC), with peculiar consequences on the North Atlantic Drift (NAD) and on the formation of North Atlantic Deep Waters (NADW) (e.g. Bond et al., 1992; Bond and Lotti, 1995; Broecker, 1997; Kissel et al., 1999a; Alley et al., 1999; Clark et al., 2002; Ramhstrof, 2002; Broecker, 2003; Hemming, 2004). Even though these phenomena are now relatively well identified, the causes and consequences of such climatic changes and dynamic interactions between ice, ocean and atmosphere remain uncertain. For instance, the role of ice shelves developed at the margins of European ice sheets during the last glacial period has probably been underestimated, as suggested by recent works (Hulbe et al., 2004; Alvarez-Solas et al., 2010). There is also a need for a better definition of the geographical fingerprint of such events to help identifying the likely source regions and perturbation mechanisms (Roche et al., 2010).

Here we propose to reconstruct the paleoclimatic and paleoceanographic setting of the southern Faeroe Islands during MIS3 in order to explore the evolution of the surface Atlantic Ocean under the influence of growing European ice sheets. To reach this goal, analysis of organic-walled dinoflagellate cyst (dinocyst) assemblages was undertaken on core MD99-2281, retrieved off SW Faeroe, and quantifications of surface hydrological parameters were obtained from ecological transfer functions (the modern analogue technique - MAT, e.g. Guiot and de Vernal, 2007) applied to these assemblages. Dinocysts have long since been used as seasurface paleohydrological proxies, as their modern biogeographical distribution in surface sediments appears to be tied to ecological parameters of the overlying surface water masses (e.g. Harland, 1983; Rochon et al., 1999a,b, 2008; Marret and Zonneveld, 2003; de Vernal and Marret, 2007). Dinocysts are organic microfossils and derive from the sexual reproduction of dinoflagellates. The wall of dinocysts, comparable to the sporopollenin of pollen grains, has been called dinosporin (e.g. De Leeuw et al., 2006) and confers to dinocysts a strong resistance to dissolution, and a good fossilization potential (e.g. Evitt, 1985; Rochon et al., 1999a,b; Marret and Zonneveld, 2003). Recent studies however suggest that this compound is in fact closer to cellulose than to sporopollenin (e.g. Versteegh et al., 2012), but their preservation potential is still high, even if the assemblages can be altered by oxidation processes in some specific environments (e.g. Zonneveld et al., 2007; Bogus et al., 2012). They are among the rare proxies offering access to past hydrological conditions of polar and/or glacial extreme environments (e.g. de Vernal and Rochon, 2011).

In addition, our study compiles a set of multi-proxy data (x-ray fluorescence - XRF - core scanning, magnetic properties, abundances of the polar planktonic foraminifera Neogloboquadrina pachyderma s and IRD concentrations) that contributes to document and discuss the response of the ocean during MIS3.

\section{Environmental setting}

\subsection{Modern oceanic and sedimentological setting}

\subsubsection{Physiography}

Core MD99-2281 $\left(60^{\circ} 21^{\prime} \mathrm{N}, 09^{\circ} 27^{\prime} \mathrm{W}\right)$ was retrieved by the RV Marion-Dufresne during the IMAGES (International Marine Global Change Study) V - MD99-114 cruise (Labeyrie et al., 1999). It is made of 29 meters of hemipelagic silty clays (Labeyrie et al., 1999; Boulay, 2000). The core was collected at $1197 \mathrm{~m}$ deep at the foot of the Faeroe Bank located at the northern end of the Rockall Trough (Figs. 1 and 2). It has been retrieved at a location where seismic continuous parallel draping internal reflectors (see seismic section $\mathrm{C}$ in Boldreel et al., 1998) have been attributed to pelagic sediments deposited in a low-energy, deep-water environment, unaffected by the strong current activity (Boldreel et al., 1998).

Sediment accumulation in the Rockall Trough is primarily constrained by bottom currents (Kuijpers et al., 2002). This trough extends from $53^{\circ}$ to $60^{\circ} \mathrm{N}$ west of the UK, with water depths ranging from $4000 \mathrm{~m}$ (southern part) to $1000 \mathrm{~m}$ (northern part). The topography is relatively complex (Masson et al., 2002). The northwest margin is bordered by three separate seamounts (George Bligh, Lousy and Bill Bailey's) 


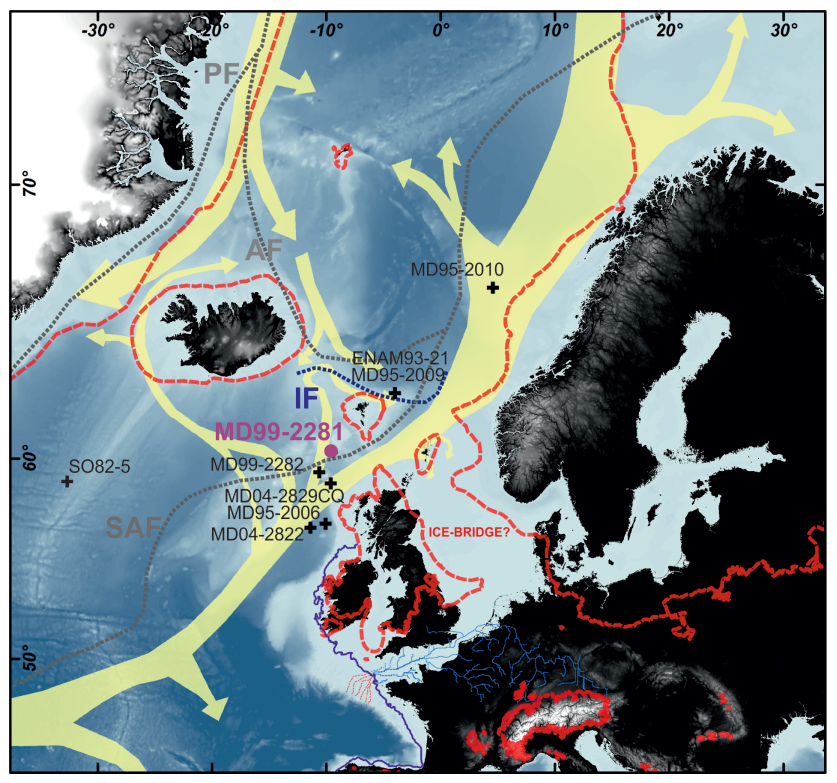

Fig. 1. Location of the studied core (MD99-2281: this work) and other cores discussed in the paper (MD95-2009; MD95-2010 - Eynaud et al., 2002; ENAM93-21 - Rasmussen and Thomsen, 2004; core SO82-5 - Van Kreveld et al., 2000; MD04-2822; MD952006 - Knutz et al., 2001; Hibbert et al., 2010; MD04-2829CQ - Hall et al., 2011). The yellow arrows depict the pathway of the main modern surface currents (Fogelqvist et al., 2003). Dotted grey lines locate major modern hydrographic fronts: $\mathrm{PF}=$ Polar Front, $\mathrm{AF}=$ Arctic Front, SAF: Sub-Arctic Front (Dickson et al., 1988). The IF = Iceland Faeroe Front is indicated by the dark blue dotted line (Rasmussen et al., 2002b). The palaeogeography of the adjacent European continent during the Last Glacial Maximum with the hydrographic system/paleovalleys of the Manche River (Lericolais et al., 2003) and the paleo-coastline (bold blue line) at $21 \mathrm{kaBP}$ (Bourillet et al., 2003) are also depicted. The full glacial extension of the North Hemispheric ice sheets (Grosswald and Hughes, 2002, and Ehlers and Gibbard, 2004) is schematized by the red dotted-line.

culminating at more than $500 \mathrm{~m}$ water depth. The merging of the different deep channels between these seamounts forms a connection between the Rockall Trough and the Iceland Basin (Fig. 2).

In the northeastern part, the Rockall Trough is bordered by the Faeroe Bank (FB) and the Wyville-Thompson ridge culminating at less than 100 and $500 \mathrm{~m}$ water depths, respectively (Bett, 2001, Fig. 2). The barrier, which separates the Faeroe Bank Channel and the Faeroe Shetland Channel, plays an essential role in the distribution of water masses and the dynamic of bottom currents (Kuijpers et al., 2002). These landforms are the result of the opening of the North Atlantic basin during the Lower Eocene, and post-rift tectonic events that followed (Howe et al., 2006).
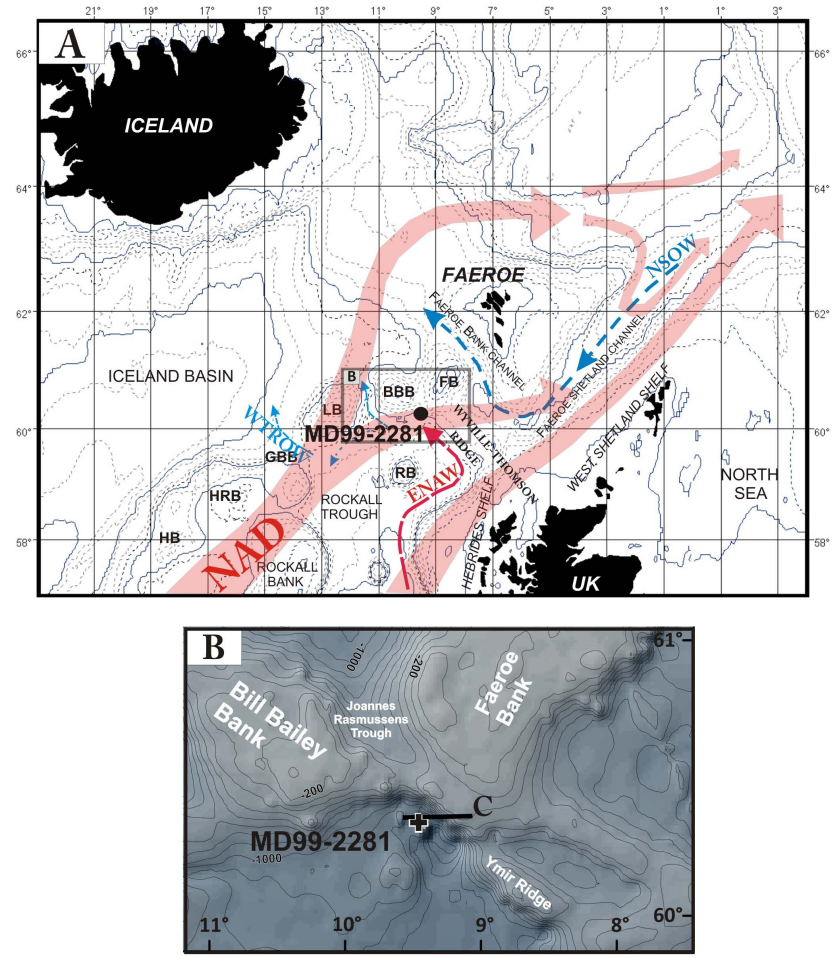

Fig. 2. Detailed physiography of the studied area. (A) Isobath: the first depth contour represents the $200 \mathrm{~m}$ isobar on the shelf. The next depth contour is the $1000 \mathrm{~m}$ isobar. At water depths greater than $1000 \mathrm{~m}$, the distance between the isobars is $1000 \mathrm{~m}$. Bill Bailey's Bank (BBB), Faeroe Bank (FB), George Bligh Bank (GBB), Hatton Bank (HB), Hatton-Rockall Basin (HRB), Lousy Bank (LB), Rosemary Bank (RB) (Howe et al., 2006). Surface and subsurface Currents: North Atlantic Drift (NAD), East North Atlantic Water (ENAW). Bottom currents: Norwegian Sea Overflow Water (NSOW), North East Atlantic Deep Water, Wyville-Thompson Ridge Overflow Water (WTROW) (Kuijpers et al., 1998, 2002; Holliday et al., 2000; New and Smythe-Wright, 2001; Howe et al., 2006). (B) Bathymetric map (contour interval $100 \mathrm{~m}$ ) zooming on the core site with location of the $\mathrm{C}$ seismic section documented by Boldreel et al. (1998), who identified pelagic deposits unaffected by currents in the coring area.

\subsubsection{Hydrographic and oceanographic setting}

The dynamic of surface currents in the Rockall Trough area is primarily driven by the influence of two major gyres: the subtropical anticyclonic and subpolar cyclonic North Atlantic gyres. The latter is characterised by numerous streams, including the well-known poleward current of the NAD, which defines a peculiar distribution pattern of fronts and water masses in the area. The topography of the region, and more specifically the presence of Iceland, forces the penetration of the NAD across the "Iceland-Faeroe-Scotland" ridge where our study site is located. The NAD splits into two branches in the vicinity of the Faeroe Islands (Figs. 1 and 2; Larsen et al., 2008, 2009). 
Core MD99-2281 is presently located under the influence of the modified North Atlantic surface waters, between the Arctic Front (AF) to the north and the sub-Arctic Front (SAF) to the south (Fig. 1). The modern sea-surface temperature (SST) in the area varies from $8^{\circ} \mathrm{C}$ during winter to $12^{\circ} \mathrm{C}$ during summer (WOA, 1998). Below the surface, the watermass distribution and deep circulation are governed by the bathymetric complexity of the sector (Fig. 2, Holliday et al., 2000).

The first $1000 \mathrm{~m}$ of the water column are occupied by a relatively homogeneous body of water whose temperature and salinity ranges characterise the East North Atlantic Water (ENAW, Holliday et al., 2000; New and SmytheWright, 2001). Below dominates the North East Atlantic Deep Water (NEADW). A core of this water enters the Trough from the south and, trapped by the topography to the north, makes a cyclonic gyre, joining the Wyville-Thompson Ridge Overflow Water (WTROW) to continue its trajectory into the Iceland Basin (Howe et al., 2006). North of the Wyville-Thompson Ridge, the Norwegian Sea Overflow Water (NSOW) migrates southward across the Faeroe Shetland Channel and then turns west to enter the Faeroe Bank channel (Kuijpers et al., 2002) to join the southern flank of the Iceland-Faeroe Ridge. The NSOW intermittently crosses the Wyville-Thompson Ridge to join the LSW, then reaching our core location (Holliday et al., 2000; New and SmytheWright, 2001; Kuijpers et al., 1998, 2002; Rasmussen et al., 2002b).

\subsection{Paleoclimatic interest}

Previous paleoceanographic studies have demonstrated the high sensitivity of the Faeroe area to millennial-scale climatic variability and its intimate relation to the MOC dynamics (Rasmussen et al., 1996a ,b, 2002a,b, 2008; Rasmussen and Thomsen, 2004, 2008; Eynaud et al., 2002; Voelker, 2002). During the last glacial period, the southern part of the Faeroe Islands was under the direct influence of the proximal European ice sheets (Fennoscandian ice sheet: FIS and the British-Irish ice sheet: BIIS) (Fig. 1). Therefore, core MD99-2281 has likely recorded the history of these ice sheets at a millennial scale, especially episodes of decay (including those of HEs) which occurred during MIS3, together with changes in the penetration and vigour of the NAD current, and in the latitude of the Arctic Front. In addition, our site may have recorded instabilities of the marine extensions of the ice sheets, i.e. ice shelves that are up to now poorly considered in HE dynamics (Hulbe et al., 2004; Alvarez-Solas et al., 2010). Another point concerns the potential existence of an "ice bridge" in the North Sea joining the BIS to the FIS between 30 and $25 \mathrm{cal} \mathrm{kaBP}$. The presence of this ice bridge is still strongly debated, even if this hypothesis has gained increasing acceptance in recent years (Bradwell et al., 2008; Scourse et al., 2009; Hibbert et al., 2010; Chiverrell and Thomas, 2010; Toucanne et al., 2010).
Instabilities of proximal glaciers have had a major impact on the surface hydrology of the region and have strongly influenced the NAD, and, consequently, the NADW overflow from the Nordic Seas (e.g. Bond et al., 1992; Bond and Lotti, 1995; Broecker, 1997, 2003; Hemming, 2004).

\section{Material and methods}

Core MD99-2281 has been sampled every $10 \mathrm{~cm}$ between 2090 and $1200 \mathrm{~cm}$. The 90 samples were then wet sieved to separate fractions above and below $150 \mu \mathrm{m}$. Both fractions were analyzed separately. Planktonic foraminiferal assemblages and ice rafted detritus (IRD) concentrations were determined on the $>150 \mu \mathrm{m}$ fraction, whereas palynological analyses (dinocyst assemblages, freshwater algae) were conducted on the $<150 \mu \mathrm{m}$ one.

\subsection{Dinoflagellate cysts (dinocysts)}

\subsubsection{Dinocyst assemblage analysis}

Palynological preparations follow the protocol described by de Vernal et al. (1996), slightly modified at EPOC laboratory (cf. http://www.epoc.u-bordeaux.fr/index.php?lang=fr $\backslash$ \&page=eq_paleo_protocoles for details). The dinocyst specific determination was done with a Leica Microscope at a X400 magnification. Around 300 dinocysts were counted in each sample to obtain a good statistical representation of the assemblage. Species identification follows Rochon et al. (1999b). Relative abundances were calculated relative to the total sum of Quaternary dinoflagellate cysts and absolute abundances (concentration cysts $/ \mathrm{cm}^{3}$ of dried sed.) were obtained thanks to the marker grain method (Lycopodium tablets, de Vernal et al., 1996; Mertens et al., 2009). Counts of non-Quaternary reworked dinocysts were done in order to evaluate the ratio $\mathrm{Rd} / \mathrm{Md}$ [reworked dinocysts/modern dinocysts] which along the western European margin could provide a proxy of terrigeneous advection (e.g. Zaragosi et al., 2001; Eynaud et al., 2007; Penaud et al., 2009).

\subsubsection{Transfer functions}

An ecological transfer function has been applied to the raw data derived from the counts (relative abundances) to quantitatively reconstruct the sea-surface paleohydrological parameters. The transfer function was performed with the R software (" $\mathrm{R}$ " version 2.7.0, R Development Core Team, 2008) using a script developed by Guiot and Brewer (www.cerege.fr/IMG/pdf/formationR08.pdf) for the modern analogue technique (MAT, e.g. Guiot and de Vernal, 2007). This statistical tool principally uses the statistic distance between fossil (paleoceanographic record) and current (modern database) assemblages. Modern dinocyst assemblages are compiled in a geo-referenced database of marine surface sediment samples. The database we used here is that 
of de Vernal et al. (2008) with 1189 stations from North Atlantic, Arctic and North Pacific oceans and their adjacent seas (see recurrent updates at http://www.geotop.ca/fr/ bases-de-donnees/dinokystes.html). Calculations rely on a weighted average of SST values (compiled from the 2001 version of the World Ocean Atlas) from the best five modern analogues, with a maximum weight given for the closest analogue in terms of statistical distance, i.e. dissimilarity minimum (e.g. Kucera et al., 2005; Guiot and de Vernal, 2007). Among the sea-surface parameters that we can reconstruct on the basis of dinocysts are SSTs and sea-surface salinities (SSSs) for the warm season, i.e. mean summer (June-July-August average), the cold season, i.e. mean winter (January-February-March average), the warmest (August) and the coldest (February) months of the year, but also the sea-ice cover duration (months per year). The reader is referred to Guiot and de Vernal (2007, 2011a,b) for a review of the theory of transfer functions, and to de Vernal et al. (2001, 2005) for a step-by-step description of the application of transfer functions to dinocysts, including discussion about the degree of accuracy of the method.

Standard deviations must be taken into account in the reconstituted hydrological parameters because of the accuracy of the database calibration. They have been established by comparing the predictions provided by the transfer function and direct instrumental measurements made on surface waters. The root mean square errors of prediction (RMSEP) for the parameters presented in this paper are $\pm 1.1^{\circ} \mathrm{C} \pm$ and $1.6^{\circ} \mathrm{C}$ for SST of February and August, respectively, and \pm 1.1 months per year for the ice cover duration (Penaud, 2009). They are \pm 2.2 and 2.5 psu for February and August SSS, and \pm 2.3 and 2.4 psu for mean winter and mean summer SSSs, respectively. The relatively large error for salinity prediction is due to the inclusion of Arctic sites characterised by low and highly variably salinities (down to 11). In the $>30$ salinity domain, the error of prediction is 0.63 (Eynaud et al., 2012). Associated and additional information is listed on the GEOTOP website (http://www.geotop.ca/).

\subsection{Magnetic properties}

The core has been sub-sampled using u-channels to perform detailed magnetic analyses. In order to complement onboard susceptibility measurements made with a large diameter coil (low resolution), magnetic susceptibility has been repeated at the LSCE with a 45-mm diameter MS2-C Bartington coil. The data were generated every $2 \mathrm{~cm}$ on the uchannels and they were normalized by the volume to get the volume susceptibility $(\kappa)$. The natural remanent magnetization (NRM) was measured using a 755-R 2G cryogenic passthrough magnetometer, equipped with a high resolution set of coils and placed in the $\mu$-metal shielded room of LSCE (see Kissel et al., 1999b for detailed laboratory procedures). An in-line alternating field (AF) demagnetization unit was used for the stepwise demagnetization at 5, 10, 15, 20, 25, 30, 35,
$40,45,50,60$ and $80 \mathrm{mT}$. After demagnetization at $80 \mathrm{mT}$, 87 to $97 \%$ of the initial magnetization was removed. The anhysteretic remanent (ARM) and isothermal remanent (IRM) magnetizations were acquired and demagnetized also on $\mathrm{u}-$ channels using the same method and instruments. ARM was acquired along the vertical geographical axis in a peak alternating field of $100 \mathrm{mT}$ and a steady bias field of $50 \mu \mathrm{T}$. During acquisition, the samples were translated through the coils at a speed of about $1 \mathrm{~cm} \mathrm{~s}^{-1}$ (Brachfeld et al., 2004). After acquisition, the ARM was then progressively demagnetized using 10 steps at $10,15,20,25,30,35,40,50,60$, and $80 \mathrm{mT}$. Saturated IRM (SIRM) was then acquired, also along the vertical geographical axis in six steps $(0.05,0.1,0.2,0.3,0.5$ and $1 \mathrm{~T}$ ) using a $2 \mathrm{G} 1.6 \mathrm{~m}$ long pulsed solenoid and stepwise demagnetized using the same 10 steps as for the ARM. During the demagnetization of NRM, ARM and IRM, the u-channels were translated at a speed of about $4 \mathrm{~cm} \mathrm{~s}^{-1}$ through the demagnetization coils. All the data were acquired using software developed at LSCE, which allow to considerably reduce the translation speed during the measurements while the $\mathrm{u}$ channel passes through the pick-up coil. This is particularly adapted to the measurements of very high magnetizations as the ones of core MD99-2281 because the reduced translation speed allows to reliably count the flux jumps. Previous works already conducted in the area established that the main magnetic mineral is magnetite (Kissel et al., 1999a; Ballini et al., 2006). The co-variations obtained between the low field magnetic susceptibility, the ARM and the IRM data therefore indicate that these parameters are only concentration dependent in this sediment (except during HE4, see below).

\subsection{XRF (x-ray fluorescence) elementary analyses}

A non-destructive X-ray fluorescence (XRF) scan of the core was done using the CORTEX scanner at a resolution of $2 \mathrm{~cm}$ (Richter et al., 2006). To complement these data, a high resolution scan (every $2 \mathrm{~mm}$ ) was done at EPOC laboratory with the Avaatech XRF Core Scanner on the sections (990$2100 \mathrm{~cm}$ ) investigated for dinocysts. This provides us with a semi-quantitative approach of the sediment chemical composition (for major and some minor chemical elements), and thus permits estimation of changes in the nature of sediments along time. Richter et al. (2006) demonstrated on the basis of the low resolution XRF scan of a proximal core MD99$2282\left(59^{\circ} 29^{\prime} \mathrm{N} ; 10^{\circ} 34^{\prime} \mathrm{W}\right)$ that the abundance of some elements, such as $\mathrm{Ca}$, or the ratio $\mathrm{K} / \mathrm{Ti}$, provides information about glacial-interglacial alternances. It was also observed by Ballini et al. (2006) at the DO scale. Among other applications of the XRF tool, the ratio $\mathrm{K} / \mathrm{Ti}$ could provide information about lithic grain sources, and the $(\mathrm{Fe}+\mathrm{Ti}) /(\mathrm{Ca}+\mathrm{Sr})$ ratio further gives access to the proportion of lithogenic versus biogenic components within the sediments. The variations in $\mathrm{Fe}, \mathrm{Mn}$ and $\mathrm{S}$ abundances further help to identify early diagenesis processes (Mojtahid et al., 2005, Richter et al., 2006). 


\subsection{Analysis of the coarse fraction $>150 \mu \mathrm{m}$}

\subsubsection{Planktonic foraminifera}

These calcareous-walled protists form part of the zooplankton, and their geographical distribution covers almost all oceans (e.g. Kucera, 2007). There are currently about forty species in the modern assemblage of planktonic foraminifera. One of the mesopelagic species well known and frequently used in paleoclimatology and biostratigraphy is the polar taxon, Neogloboquadrina pachyderma sinistral (NPS) coiled form. Quantification of this taxon abundance $(\%)$ in the planktonic assemblages provides access to a qualitative estimate of surface water temperatures, and depending on the areas, directly follows the Polar Front migrations (e.g. Ericson, 1959; Eynaud et al., 2009). Counts of the relative abundances of this species have been made on known aliquots of the dried $>150 \mu \mathrm{m}$ residues (total sum of planktonic foraminifera of minimum 300 specimens) from the same samples studied for dinocyst assemblages.

In addition, stable isotope measurements were done on NPS shells. Specimens were picked out from the 200$250 \mu \mathrm{m}$ fraction and analysed at EPOC using an Optima Micromass mass spectrometer. For each measurement, $80 \mu \mathrm{g}$ mean weight aliquots (5 to 6 specimens) were treated with individual acid baths. The extracted $\mathrm{CO}_{2}$ gas was analyzed versus a laboratory reference gas calibrated with respect to VPDB (Vienna Pee Dee Belemnite) using the international standard NBS 19. For this paper, only $\delta^{18} \mathrm{O}$ data will be discussed.

\subsubsection{Ice-rafted debris}

In hemipelagic cores, ice rafted detritus (IRD) are generally determined in the coarse lithic $>150 \mu \mathrm{m}$ grain fraction. These large lithic grains (LLG) are actually torn-off bedrock under ice sheet dynamic processes. They were disseminated by icebergs throughout the North Atlantic Ocean during icesheet calving events, as for instance during Heinrich events (Heinrich, 1988; Bond et al., 1992; Bond and Lotti, 1995; Elliot et al., 2001; Broecker, 2003; Hemming, 2004). The study of IRD concentrations (number of LLG $>150 \mu \mathrm{m} \mathrm{g}^{-1}$ dry sediment) thus provides a way to document ice-sheet dynamics throughout time. The LLG were counted in the same samples as those used for NPS relative abundance characterisation. Their raw number per samples varies from 64 to 955 grains per g of dry sediment.

\section{Stratigraphy of the core}

Nine AMS ${ }^{14} \mathrm{C}$ dates measured on planktonic foraminifera monospecific samples (cf. Table 1) have been obtained on the topmost eleven meters of core MD99-2281 (Table 1, Boulay, 2000), providing a first stratigraphic frame between 10 and $24 \mathrm{kacal}$ BP. For this work, four supplementary AMS ${ }^{14} \mathrm{C}$ dates were obtained between 12 and $19 \mathrm{~m}$ in the core. Regarding the time period we consider for this paper, radiocarbon dates were calibrated using the "glacial polynomial" from Bard (1998) and Bard et al. (1998), which provides calibration up to $36{ }^{14} \mathrm{C}$ ka BP (Table 1).

Following several paleoceanographic studies in the area (Rasmussen et al., 1996b, 1997; Kissel et al., 1999a; Eynaud, 1999; Stoner et al., 2000; Laj et al., 2000), these age control points were combined to tie-points generated by the comparison of the record of magnetic concentration parameters to the NGRIP-GICC05 $\delta^{18} \mathrm{O}$ record (Svensson et al., 2008), i.e. the recommended North Atlantic regional stratotype (Austin and Hibbert, 2012). The rationale is that marine records of magnetic concentration parameters from MIS3 are consistent across the North Atlantic Basin on the path of different overflow branches of the NADW and could be tied on the high frequency climatic variability (DO cycles, e.g. Sanchez-Goñi and Harrison, 2010; Wolff et al., 2010) characteristic of this period (e.g. Kissel et al., 1999a). This approach is comparable to an event-based stratigraphy and has recently been acknowledged as one of the most robust ways to establish age models for marine sediments (Austin and Hibbert, 2012).

Our stratigraphy has thus been constructed by linking the magnetic concentration increases to the beginning of Greenland interstadial (GIs) warmings (Austin and Hibbert, 2012 recommended protocol) and conversely, the magnetic concentration decreases to Greenland stadial (GS) coolings (Fig. 3). The chronostratigraphic ages used for this work conform to the recent update done by Wolff et al. (2010) on DO events. As a result, 18 stratigraphic control points have been added to the AMS ${ }^{14} \mathrm{C}$ dates (Table 1, Fig. 3). The age model has been constructed on the basis of a linear interpolation between tie points (Table 1, Fig. 4) giving an average sedimentation rate of about $80 \mathrm{~cm} \mathrm{ka}^{-1}$ for the studied period.

Additional tie points, independent from climate, are also retrieved from the record of the changes in the Earth's magnetic field intensity, namely the two prominent lows attributed to the Mono Lake (MLE) and to the Laschamp (LE) excursion (Laj et al., 2000). Due to the modulation of cosmogenic isotopes production by the dipolar Earth magnetic field, these two excursions have their counterpart in the ${ }^{10} \mathrm{Be}$ and ${ }^{36} \mathrm{Cl}$ records from ice (Wagner et al., 2000). Therefore, they allow a robust correlation between ice and sediment climatic records. In both archives, the MLE occurred during GS7 and the LE is centered on GI10. We observe that both are at the right place in core MD99-2281 (Figs. 3 and 4), giving confidence on the correlation discussed above. 


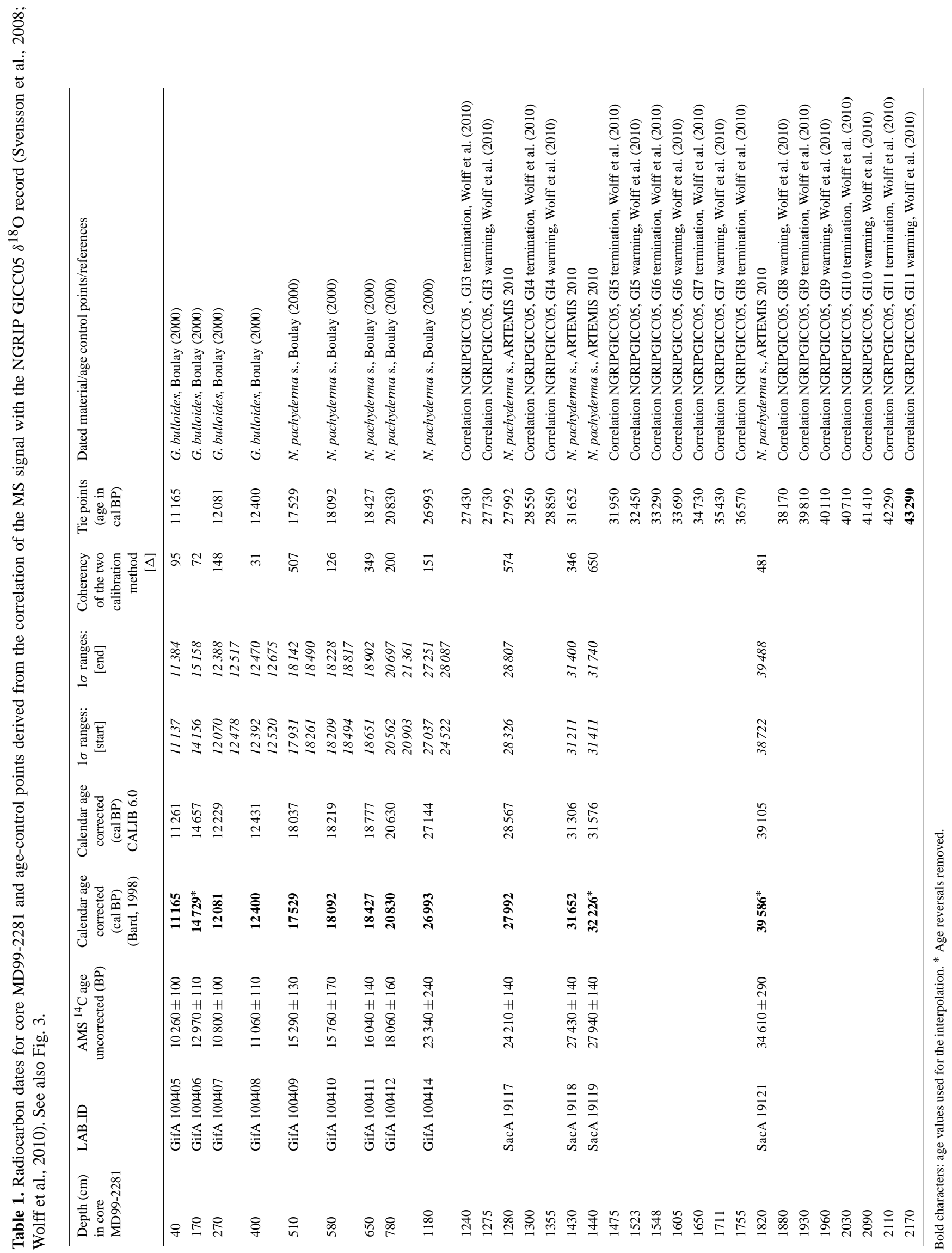




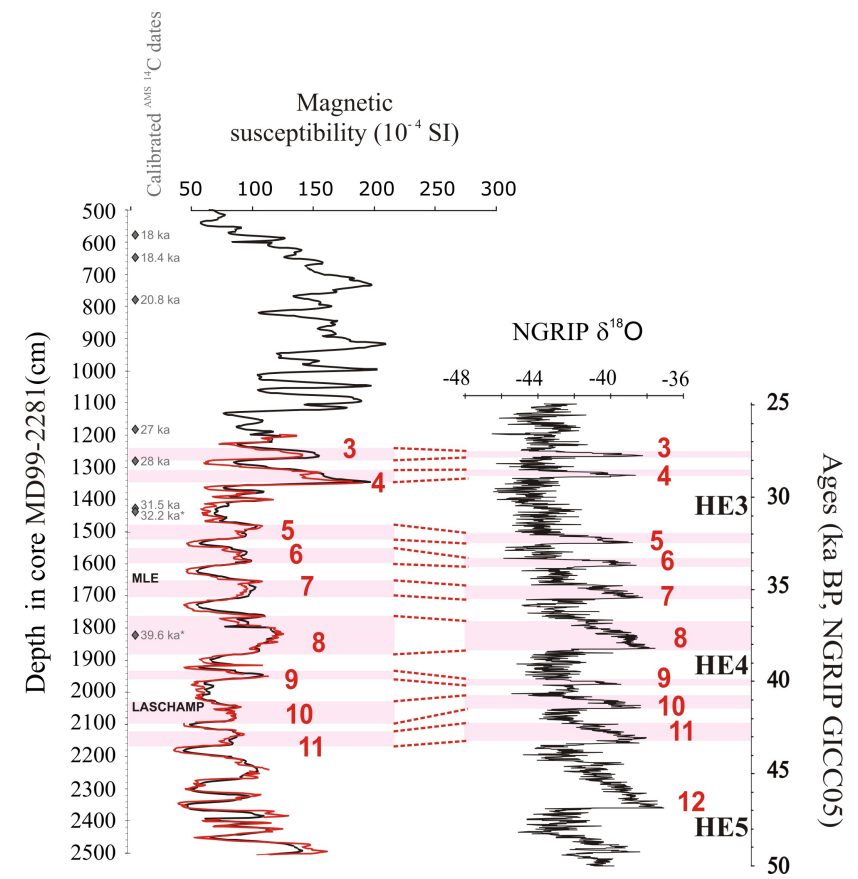

Fig. 3. Magnetic susceptibility (MS) record from core MD99-2281 (dark line $=$ onboard data versus red line $=$ low field magnetic susceptibility) and its correlation to the NGRIP GICC05 $\delta^{18} \mathrm{O}$ record (Svensson et al., 2008) to define supplementary age control-points over the MIS3 period. See also Table 1. Pink bars underline GIs, labels and limits after Wolff et al. (2010). The horizons having recorded the geomagnetic excursions (MLE for Mono Lake excursion and Laschamp) are also indicated.

\section{Results}

\subsection{Dinocyst data}

Thirty dinocyst taxa were identified in the MIS3 assemblages. Their absolute abundances in the sediment (concentrations) are high and vary between 1000 and 90000 cysts $/ \mathrm{cm}^{3}$ along the studied section, with a mean value around 10000 cysts $/ \mathrm{cm}^{3}$ (Fig. 5). As a whole the dinocyst concentrations follow the MS properties data, thus indicating maximum dinocyst production and/or deposition and/or preservation to the studied site during warm GIs, and conversely during cold GSs. Some strong excursions were recorded over the studied interval, with especially two peaks in concentrations of about 90000 and $57000 \mathrm{cysts} / \mathrm{cm}^{3}$ at 1660 and $1950 \mathrm{~cm}$ depths, respectively.

The assemblages are dominated by five species (Fig. 5, Table 2), which are: Bitectatodinium tepikiense (largely dominates the assemblages), Operculodinium centrocarpum, Brigantedinium spp., Islandinium minutum (upper part of the section), and Pentapharsodinium dalei (lower part of the section). Table 2 summarizes the most salient features recorded for the encountered species both at present and along the studied section of core MD99-2281. The

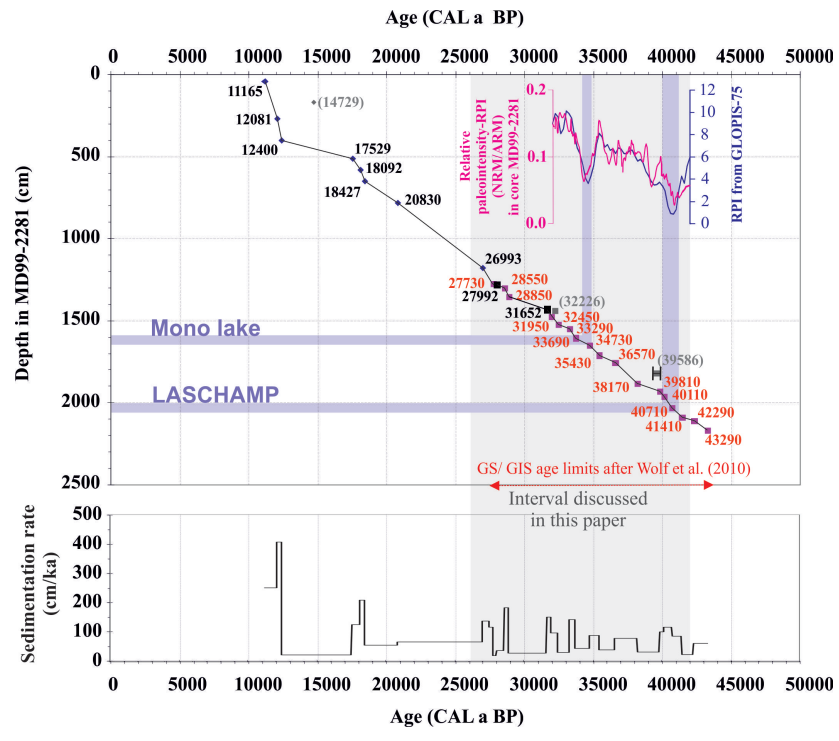

Fig. 4. Age model and sedimentation rates for the last $50 \mathrm{ka} \mathrm{BP}$ in core MD99-2281 (see also Table 1). Dates in red are those deduced from the correlation (see also Fig. 3) of the MS record and the NGRIP GICC05 $\delta^{18} \mathrm{O}$ (Wolff et al., 2010). A comparison of the relative paleointensity (RPI) record from core MD99-2281 with the reference RPI curve of GLOPIS-75 is shown for the $32-42 \mathrm{ka}$ interval.

continuous presence along the record of specimens from the genus Brigantedinium, with occurrence of other peridinioidspecies, indicate that the alteration of the assemblage by oxygenation processes (e.g. Zonneveld et al., 2007) was not intense. This is also supported by high dinocyst concentrations in the sediments during GIs which record active deep-sea circulation (e.g. Kissel et al., 1999a), and thus better ventilation.

\subsection{Sea-surface paleohydrology (from dinocyst transfer function) during MIS3}

The sea-surface paleohydrological conditions quantified on the basis of the dinocyst MAT transfer function (database 1189) are shown in Fig. 5 (right panel).

In the studied section, August SSTs vary between 8.5 and $17^{\circ} \mathrm{C}$, with a mean around $16^{\circ} \mathrm{C}$, and February SST between 6 and $-1^{\circ} \mathrm{C}$. The reconstructed February SSTs are considerably lower than the modern ones over the area, which fluctuate around an average of $8.7^{\circ} \mathrm{C}$ (WOA, 1998). In contrast, the reconstructed August SSTs are well above the modern averages of $12.1{ }^{\circ} \mathrm{C}$ (WOA, 1998). Our reconstructions indicate that a positive anomaly of nearly $4^{\circ} \mathrm{C}$ (in comparison to the modern conditions) was recorded over the area during MIS3 in summer.

Sea-ice cover duration varies between 0 and 2 months/year along the main part of the section, except in the topmost part of the studied section where it reaches values up to 5 months per year. These values are above the modern ones, the area being presently free of sea-ice even in winter, but are still 


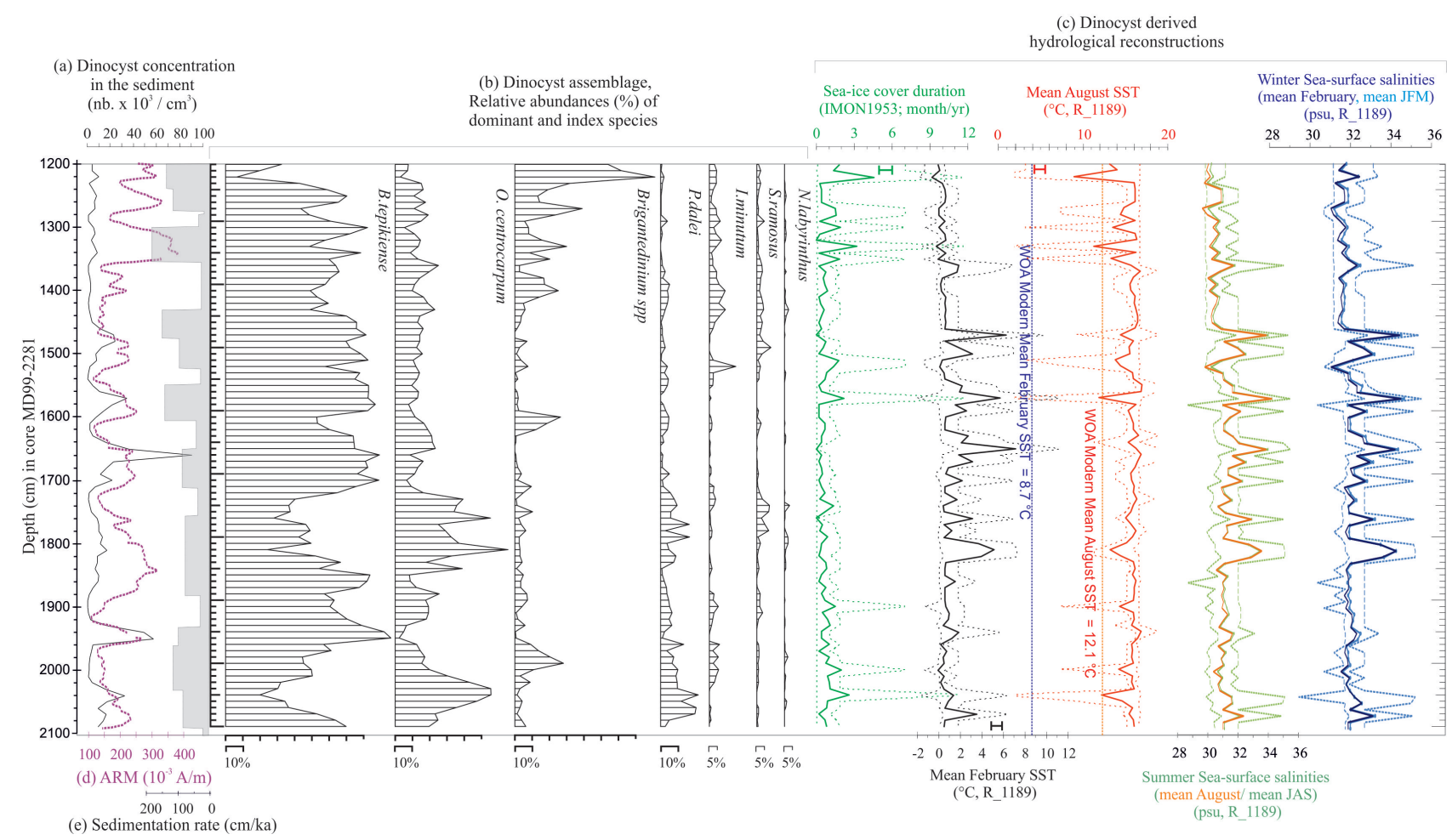

Fig. 5. Results from dinocyst analyses (see also Table 2) over the section 1200-2100 cm in core MD99-2881, with (a) dinocyst total concentrations in the sediment (nb. of cyst/cm ${ }^{3}$ of dry sed.); (b) relative abundances of some selected species; (c) Dinocyst derived reconstructions (modern analogue technique) of sea-surface conditions (sea-ice cover duration \pm 1.1 months per year; February SST $\pm 1.1^{\circ} \mathrm{C}$; August SST $\pm 1.6^{\circ} \mathrm{C}$; February SSS \pm 2.2 ; August SSS \pm 2.5 ; mean winter SSS \pm 2.3 ; mean summer \pm 2.4 psu). The dotted lines surrounding each reconstructed parameter correspond to minima and maxima values found in the set of the 5 selected analogues. Modern values of SSTs after WOA (1998). These results are compared to (d) the ARM (for anhysteretic remanent magnetization) data and (e) the sedimentation rate calculated from our age model (see Fig. 4).

very low. They should be considered rather as an index of the intermittent presence of ice, regarding the RMSEP of 1.1 months per year.

Paleosalinity reconstructions show variations within a range of $4 \mathrm{psu}$, from 30 to 34 in summer (during mean summer months, i.e. July-August-September, and mean August only) and 31 to 35 in winter (during mean winter months, i.e. January-February-March as well as February only). SSS oscillations are recorded synchronously during both seasons (same trends along our record), even if summer SSSs tend to be less saline than during winters. This is probably due to the influence of the summer melting of proximal ice sheets. Mean annual modern values over the area are of 35.3 , with a positive $\Delta 0.07$ psu difference between winter and summer seasons (WOA 2009, http://www. nodc.noaa.gov/OC5/WOA09/netcdf_data.html). Sea-surface waters were thus sensibly more brackish in the area during MIS3.

\subsection{Multiproxy compilation}

Figure 6 compiles the multiproxy dataset we obtained on core MD99-2281 between 1100 and $2100 \mathrm{~cm}$, i.e. 26.5 and $41.5 \mathrm{ka}$ cal BP $( \pm 1.6 \mathrm{ka}$ considering the GICC05 chronological uncertainty, Svensson et al., 2008). High-resolution XRF data are compared to MS data, planktonic foraminifera data and to large lithic grain (LLG $>150 \mu \mathrm{m})$ concentration in the sediment, this latter indicating IRD arrivals on site.

The XRF data show a high variability in correlation with changes in magnetic records (Fig. 6) with each minimum in magnetic concentration corresponding to a minimum in the $\mathrm{XRF}$ calcium detection curve $\left({ }^{\mathrm{XRF}} \mathrm{Ca}\right)$, and conversely maxima in magnetic concentration matching maxima in ${ }^{X R F} \mathrm{Ca}$. This indicates that the magnetic concentration record does not result from a dilution effect by calcium carbonate and really illustrates changes in the input of magnetites by overflow water, as for the other cores distributed along the path of the NADW. This correlation also suggests relatively low biogenic calcareous inputs (Richter et al., 2006) during stadial periods, alternating with higher inputs during interstadials. At the opposite, interstadials record increases in the ${ }^{\mathrm{XRF}} \mathrm{Ca}$ 


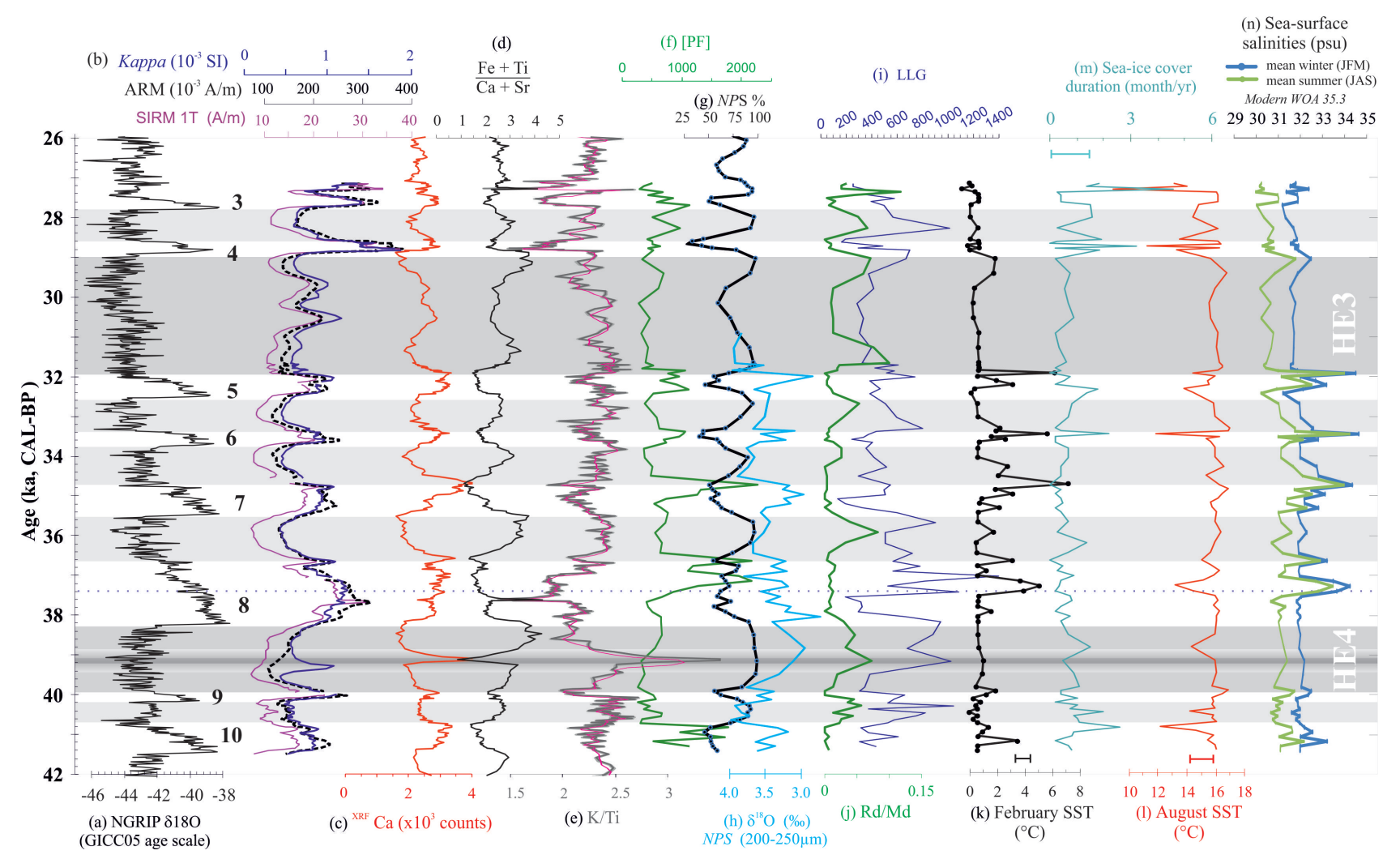

Fig. 6. Multiproxy results obtained on the MIS3 section of core MD99-2281 compared to the (a) $\delta^{18}$ O NGRIP GICC05 record (Svensson et al., 2008), with: (b) Magnetic properties (volume susceptibility - Kappa - ARM; Isothermal Remanent - IRM - magnetizations); XRF data with (c) $\mathrm{Ca}$ raw counts, (d) ratio $(\mathrm{Fe}+\mathrm{Ti}) /(\mathrm{Ca}+\mathrm{Sr})$ and (e) ratio K/Ti (pink curve: smoothed 3 points running average); (f) planktonic foraminifera absolute concentration in the sediment $([\mathrm{PF}]=\mathrm{Nb}$. of shells $>150 \mu \mathrm{m}$ per $\mathrm{g}$ of dry sed.); (g) relative abundances $(\%)$ of the polar taxon N. pachyderma sin. (NPS); (h) $\delta^{18} \mathrm{O}$ measurements on monospecific samples of NPS shells $(200-250 \mu \mathrm{m})$; (i) Large lithic grain concentration in the sediment ( $L L G=\mathrm{Nb}$. of grain $>150 \mu \mathrm{m}$ per $\mathrm{g}$ of dry sed.); (j) Reworked dinocyst versus modern dinocyst concentrations, i.e. $\mathrm{Rd} / \mathrm{Md}$ ratio; (k)-(n) dinocyst derived reconstructions of sea-surface conditions with (k) February SST $\pm 1.1^{\circ} \mathrm{C}$; (l) August SST $\pm 1.6^{\circ} \mathrm{C}$; (m) sea-ice cover duration \pm 1.1 months per year, (n) sea-surface salinities \pm 2.5 psu. Greenland stadials (light grey bands), including Heinrich events (dark grey bands) are defined in agreement with the stratigraphic synthesis of Wolff et al. (2010). Within HE4, the 39 ka event (see text) is highlighted.

content occurring in concordance with higher concentration of planktonic foraminifera shells in the sediment and lower NPS $\delta^{18} \mathrm{O}$ values. It is worth noting that these conditions are particularly characteristic of the interstadial terminal parts in our record.

The ${ }^{\mathrm{XRF}} \mathrm{Ca}$ is corroborated by the ratios $(\mathrm{Ti}+\mathrm{Fe}) /(\mathrm{Ca}+$ $\mathrm{Sr}$ ), K/Ti and the LLG concentration in the sediment, which together indicate strong terrigeneous input preferentially during stadials, but poor in magnetic content. The K/Ti XRF intensity ratio reflects changing provenance of the terrigenous fraction, with an enhanced ice-rafted continental crust (high $\mathrm{K})$ contribution during stadials vs. relatively more bottom current derived basaltic input (high Ti) during interstadials (cf. Ballini et al., 2006; Richter et al., 2006; Grützner and Higgins, 2010). Considerable short-term variability is superimposed upon the general stadial-interstadial pattern.

\section{Towards an integrated view of the response of sea-surface paleoenvironments south of the Faeroe Islands during MIS3}

The Marine Isotopic Stage 3 covers more than $30000 \mathrm{yr}$. Its lower stratigraphic limit is located at around $59 \mathrm{kaBP}$ (e.g. Martinson et al., 1987) and its upper stratigraphic boundary has recently been revised by Wolff et al. (2010) and positioned at the transition between GS4 and GI3 around $27.73 \mathrm{kacal}$ BP. Other previous work considered MIS3 termination at the end of HE3 after $29 \mathrm{ka}$ cal BP (Voelker, 2002; Bradwell et al., 2008; Hibbert et al., 2010).

Figure 6, integrating the most significant results of our study, summarizes salient features detected during MIS3 in core MD99-2281. If the DO structure (cold GSs versus warm GIs) is clearly recognizable in this multiproxy dataset, it is worth noting the good consistency between the different studied paleoenvironmental proxies. The highlighted 
Table 2. Summary of the ecology of the main species recorded over the studied section of core MD99-2281.

\begin{tabular}{|c|c|c|c|}
\hline Dinocyst specie & $\begin{array}{l}\text { Modern } \\
\text { bioprovinces } \\
\text { (Rochon et } \\
\text { al., 1999b) }\end{array}$ & $\begin{array}{l}\text { Known ecological preferences } \\
\text { (Rochon et al., 1999b; } \\
\text { Marret and Zonneveld, 2003; } \\
\text { de Vernal and Marret, 2007) }\end{array}$ & Presence in core MD99-2281 \\
\hline B. tepikiense & $\begin{array}{l}\text { - temperate to } \\
\text { subarctic (high } \\
\text { abundance spots } \\
\text { at the St. } \\
\text { Laurence and } \\
\text { Baltic Sea } \\
\text { outlets) }\end{array}$ & $\begin{array}{l}\text { - tolerates a wide range of SST } \\
\text { and salinities, but most } \\
\text { represented in areas when } \\
\text { summer SST exceed } 10^{\circ} \mathrm{C} \\
\text { - strong affinity for stratified } \\
\text { surface waters characterised by a } \\
\text { large seasonality (Rochon et al., } \\
\text { 1999b) }\end{array}$ & $\begin{array}{l}\text { - dominates the assemblages along } \\
\text { most of the MIS3 section with } \\
\text { percentages sometimes reaching } 95 \% \text {. } \\
\text { These atypical high values are not } \\
\text { observed at present in the North } \\
\text { Atlantic ocean surface sediments } \\
(\text { max. of } 30 \%) \text {. }\end{array}$ \\
\hline O. centrocarpum & $\begin{array}{l}\text { - observed from } \\
\text { mid to high } \\
\text { latitudes } \\
\text { - associated with } \\
\text { the North } \\
\text { Atlantic Drift } \\
\text { (NAD) pathway }\end{array}$ & $\begin{array}{l}\text { - tolerates a wide range of } \\
\text { temperatures and salinities }\end{array}$ & $\begin{array}{l}\text { - second most abundant species } \\
\text { encountered, especially at the base of } \\
\text { the section }\end{array}$ \\
\hline Brigantedinium spp. & $\begin{array}{l}\text { - ubiquitous, } \\
\text { often dominant } \\
\text { in upwelling } \\
\text { zones } \\
\text { - also associated } \\
\text { with sub-arctic } \\
\text { and arctic water } \\
\text { masses }\end{array}$ & $\begin{array}{l}\text { - tolerates a wide range of } \\
\text { temperatures, salinities and sea- } \\
\text { ice cover duration } \\
\text { - heterotrophic taxa, has been } \\
\text { related to its main food source, } \\
\text { diatoms. }\end{array}$ & $\begin{array}{l}\text { - well represented at the top of the } \\
\text { section } \\
\text { - Relatively difficult to identify at the } \\
\text { species level due to the crumbled } \\
\text { aspect of the cyst }\end{array}$ \\
\hline I. minutum & $\begin{array}{l}\text { - sub-polar to } \\
\text { polar }\end{array}$ & $\begin{array}{l}\text { - associated with long sea-ice } \\
\text { cover duration (from } 8 \text { to } 12 \\
\text { months) }\end{array}$ & $\begin{array}{l}\text { - poorly represented in our sequence, } \\
\text { except in the upper part of the section }\end{array}$ \\
\hline P. dalei & $\begin{array}{l}\text { - sub-polar to } \\
\text { polar } \\
\text { environments in } \\
\text { North Atlantic } \\
\text { basins, north of } \\
\text { the NAD }\end{array}$ & $\begin{array}{l}\text { - tolerates a wide range of SSSs, } \\
\text { SSTs, and sea-ice cover duration } \\
\text { - requires a } 4{ }^{\circ} \mathrm{C} \mathrm{SST} \mathrm{minimum} \\
\text { during summer } \\
\text { - abundant in regions with a } \\
\text { large seasonal gradient of SSTs }\end{array}$ & $\begin{array}{l}\text { - low abundances in the sequence; } \\
\text { presence most noticeable at the base of } \\
\text { the section }\end{array}$ \\
\hline
\end{tabular}

variability is well defined through qualitative data as well as through quantitative ones, with a pattern which reveals the sequencing of MIS3 millennial scale events over the area. The following discussion has been structured on this basis, considering separately GSs and GIs in order to better discriminate their specific paleoenvironments.

\subsection{Interstadials (GIs)}

The pattern detected for GIs on the basis of our study (Fig. 6) appears to be reproducible for almost all the recovered
GIs and reveals milder climatic and sea-surface conditions. ${ }^{\mathrm{XRF}} \mathrm{Ca}, \delta^{18} \mathrm{O}$ low values (signing a warm and/or meltwater advection) and the absolute abundance of planktonic foraminifera, appear together in close agreement with the reconstructed February SSTs. They all converge to indicate mean sea-surface conditions which were probably nearly as warm as the modern ones. However, detailing the internal structure of the GIs reveals pulsed warm excursions (especially well expressed in February SSTs) that are detected late during GIs, at the transition towards GSs. This is quite 
atypical considering the abruptness classically attributed to DO atmospheric warmings (Severinghaus and Brook, 1999; Lang et al., 1999; Schulz, 2002). These late events also coincide with brief decreases in summer SSTs and positive excursions in salinity, together expressing conditions closely similar to the modern ones. Other proxies reveal GIs marked by lower IRD inputs, together occurring with reduced advection of terrigeneous material (i.e. low values of the ratios $[\mathrm{Ti}+\mathrm{Fe}] /[\mathrm{Ca}+\mathrm{Sr}]$ and $\mathrm{K} / \mathrm{Ti}$, also probably linked to a dilution by an enhanced carbonate biogenic productivity), and a ratio of $\mathrm{Rd} / \mathrm{Md}$ close to zero. This suggests reduced calving from the surrounding ice sheets. The magnetic content is high at the same time as bottom currents are enhanced, transporting magnetite-rich sediments from the basaltic sill. The reconstructed sea-ice cover duration indicates GIs mostly seaice free. This is coherent with warmer SSTs recorded during winter (February) and summer (August) for most of the duration of these warm events (except within events of larger seaice duration excursions, see below). However, during GIs, our reconstructions argue for very different sea-surface conditions than the modern ones, especially because strong SST anomalies (modern versus GIs) are detected (Fig. 5): winters appear to be colder compared to modern ones $\left(-6^{\circ} \mathrm{C}\right)$ whereas summers record positive anomalies of nearly $4^{\circ} \mathrm{C}$. These anomalies are strongly reduced during warm winter excursions that mark the end of the GIs; SSTs thus tend very briefly to mirror modern conditions. Transient sea-ice cover development accompanies these peculiar events.

High relative abundances of NPS $(>80 \%)$ in the North Atlantic modern sediments mark the presence of the polar front (PF) (e.g. Eynaud et al., 2009). A shift is observed concerning this species in the vicinity of Faeroes with abundances sharply increasing north of these islands and reaching monospecific values in the Greenland Sea. Percentages up to $40 \%$ can be recorded in modern sediment of the area. The signal reconstructed in MD99-2281 during MIS3 could thus provide a record of the evolution of the PF position over the area. The pattern identified within this proxy follows the DO oscillations with GIs recording percentages close to their modern values, i.e. conditions which characterise a northern position of the PF. Along the studied section, relative abundances of NPS mirror the evolution of the ${ }^{\mathrm{XRF}} \mathrm{Ca}$ signal (Fig. 6).

\section{GI8}

The GI8 records atypical conditions. It is considered as one of the warmer MIS3 interstadials (Sanchez-Goñi et al., 2008) and is marked by a gradual cooling in ice records; its occurrence in our archive evidences at least two distinct phases. The reconstructed sea-surface conditions characterise a GI8 recording warm August SST of nearly $16^{\circ} \mathrm{C}$ during the first centuries, followed by a sharp cooling at about $37.4 \mathrm{ka} \mathrm{BP}$, which instead corresponds to warmer February SSTs and to an abrupt increase (the largest in our record) in the detrital material as documented by the LLG concentrations (Fig. 6). However, it should be noted that this transition is not accompanied by any increase in the $[\mathrm{Ti}+\mathrm{Fe}] /[\mathrm{Ca}+\mathrm{Sr}]$ or K/Ti ratios or any change in the ${ }^{\mathrm{Xrf}} \mathrm{Ca}$ or magnetic concentration. $\delta^{18} \mathrm{O}$ values indicate rapid minor oscillations within GI8, with a trend toward higher values recorded precisely when the LLG peak occurred. We also note that percentages of NPS are then relatively high compared to the other GIs, with also high absolute abundances of planktonic foraminifera shells in the sediment. This terminal phase probably relates to milder conditions (especially during the winter months, as detected by dinocysts).

\subsection{Stadials (GSs and Heinrich Events HEs)}

In our record, all GSs (underlined by grey bands on Fig. 6), except HE3, are characterised by high LLG concentrations and high abundances of NPS, coupled with high values of the ratios $\mathrm{Rd} / \mathrm{Md},[\mathrm{Ti}+\mathrm{Fe}] /[\mathrm{Ca}+\mathrm{Sr}]$ and $\mathrm{K} / \mathrm{Ti}$. Conversely, both ${ }^{\mathrm{XRF}} \mathrm{Ca}$ content and planktonic foraminiferal abundances significantly decrease. This reflects important terrigeneous advections (Matthiessen et al., 2000; Zaragosi et al., 2001; Richter et al., 2006; Ménot et al., 2006; Penaud et al., 2009). However, there are less magnetic particles than during GIs. This is related to the calving of the proximal ice sheets that does not bring magnetic particles at that time, and is combined with a reduced bottom current, while, during GIs, stronger deep currents bring magnetic particles from the Iceland plateau. The high percentages of NPS (between 80 and $100 \%$ ), accompanied by high $\delta^{18} \mathrm{O}$ values, further indicate a marked southward migration of polar waters.

These discharges are accompanied by SST approaching $0^{\circ} \mathrm{C}$ in February. However, a strong seasonality is observed during these periods as SSTs are still high in August. Such a strong seasonality occurring during GSs is at the opposite of what is at present characteristic of the area. Modern sea-surface environments are indeed strongly influenced by the penetration of the NAD, reducing the SST difference between winter and summer $\left(3^{\circ} \mathrm{C}\right.$ only). Conditions recorded during MIS3 could then be due to a globally reduced NAD influence over the site of study. The increase in seasonality we find could also be related to sea-surface conditions marked by the presence of proximal ice sheets that may have maintained cold atmospheric situations during winters. Additionally, another scenario could imply the development during summers of a thin, low salinity surface layer in relation to the seasonal melting of local ice sheets, which could be rapidly warmed up during the warm season. This atypical warm summer signal could also be related to the formation of polynias, which could have constituted patchy "hot spots" free of ice. Actually, such phenomema are observed at present in the modern Arctic Ocean, where strong winds associated or not to the upwelling of warm waters, create holes in the sea-ice cover (e.g. Platov, 2011). 


\subsubsection{Heinrich event 4 (HE4)}

Known as the largest amplitude cooling event over HEs (e.g. Cortijo et al., 1997), with in particular a very strong Laurentide ice-sheet (LIS) signature, HE4 can be divided into three phases in some parts of the Northeast Atlantic (e.g. Hemming, 2004), with a first European phase, a second longest Canadian phase, and then a terminal European phase (Snoeckx et al., 1999; Grousset et al., 2000). Multiphasing within HE4, with especially a mid-event warming, was recently reported from the central North Atlantic (Reykjanes Ridge, Jonkers et al., 2010a).

In our multiproxy dataset, a typical GSs signature is recorded for HE4, with indices suggesting ice-sheet collapse (high LLG concentrations, low $\delta^{18} \mathrm{O}$ values). Interestingly, a major peak in the ${ }^{\mathrm{XRF}} \mathrm{Ca}$ content is recorded in the middle of HE4 (around $39 \mathrm{ka}$ ). This peak is quite atypical regarding other GSs that otherwise record low ${ }^{\mathrm{XRF}_{\mathrm{C}}} \mathrm{Ca}$ values. It also differs from interstadial ${ }^{\mathrm{XRF}} \mathrm{Ca}$ maxima with respect to shape, amplitude and duration, as well as in its relationship to proxies of terrigenous input. The ${ }^{\mathrm{XRF}} \mathrm{Ca}$ peak displays a sharp onset and termination but lacks an intermittent "plateau" of roughly constant or slightly variable values; it is inverse V-shaped rather than inverse U-shaped, corresponding to a pulse rather than a period of high ${ }^{\mathrm{XRF}} \mathrm{Ca}$. The $\mathrm{Ca}$ peak during HE4 coincides with a maximum of the K/Ti intensity ratio (highest values of the entire record), while there is little if any relationship between both XRF parameters for the remainder of MIS3. Regarding data of magnetic properties, it finds echoes only in the low field magnetic susceptibility ( $\kappa$, Fig. 6), suggesting advection of large-sized magnetic grains. The pulse-like structure combined with the bulk terrigenous and magnetic signatures suggest that this anomaly may reflect an ice-rafting event, hence a detrital origin of carbonates. Relatively low ${ }^{\mathrm{XRF}} \mathrm{Sr}$ with respect to ${ }^{\mathrm{XRF}} \mathrm{Ca}$ provides further circumstantial evidence for this hypothesis, as detrital carbonates are generally depleted in $\mathrm{Sr}$ compared to biogenic ones (Hodell et al., 2008). According to Hemming (2004), high proportions of detrital carbonates characterise IRD sourced from Hudson Strait and Laurentide ice sheet. This signal might then have overlapped the European ice sheets one. In this case, changes due to local ice sheets instabilities have probably occurred before the signal that characterises the destabilization of the LIS, as featured in our record. However, this is not sufficient to suggest a precursor role of the European system (e.g. Scourse et al., 2000) for HE4. It must indeed be noted that European ice sheets finally have had the same behaviour for each GSs throughout MIS3, which attests to their sensitivity, with no evidence of asynchronicity with the LIS. Taking into account the distance between the core MD99-2281 and the Laurentide source, few IRD may have reached the area after crossing the North Atlantic, and are therefore only recorded as exceptional outburst events. This is also observed in the proximal core MD04-2829CQ further south (Fig. 1) that only records LIS-sourced IRD during a 200-300 yr period within HE4 (for the section studied in this work), which might argue for this first hypothesis (Hall et al., 2011). Another possible explanation for the peak of ${ }^{\mathrm{XRF}} \mathrm{Ca}$ could also be related to calcite secondary precipitation under anoxic bottom conditions, as suggested by some authors in the atypical sedimentological facies of HEs (Auffret et al., 1996; Zaragosi et al., 2001).

An interesting feature during HE4, but also during the others GSs, is the high SSTs during summer (August), up to $4{ }^{\circ} \mathrm{C}$ more than modern values, contrasting with the percentages of NPS that then reach nearly $100 \%$ (Fig. 6). This could suggest a strong stratification of the water masses but also emphasizes ecological strategy differences between planktonic foraminifera and dinoflagellates, the later living in the 50 upper meters of the water column while NPS can be mesopelagic (de Vernal et al., 2006; Jonkers et al., 2010b).

\subsubsection{Heinrich event 3 (HE3)}

HE3 is one of the most contentious HEs, especially from a stratigraphic point of view (e.g. Sanchez-Goni and Harrison, 2010), but also because of its atypical low IRD rate (e.g. Bond and Lotti, 1995; Grousset et al., 2001) and its strong European geochemical signature (Snoeckx et al., 1999; Grousset et al., 2000).

Our data reveal a low concentration of IRD during HE3 with two LLG peaks bracketing the event (Fig. 6), at its onset $(32 \mathrm{ka} \mathrm{BP})$ and at its termination (29 ka BP). These two low amplitude peaks correspond also to increases in the $\mathrm{Rd} / \mathrm{Md}$ and $[\mathrm{Ti}+\mathrm{Fe}] /[\mathrm{Ca}+\mathrm{Sr}]$ ratios and to minima in the ${ }^{\mathrm{XRF}} \mathrm{Ca}$, thus reflecting advection of terrigeneous material probably related to proximal ice-sheet dynamics. Abundances of NPS follow this bimodal pattern, with two periods marked by quasi-monospecific values. Conversely, dinocyst derived seasurface conditions show no characteristic excursions at this time, but rather out of phase: sea-ice cover duration increases briefly before the first IRD pulse, and just after the last one, i.e. respectively within GI5 and 4.

A clear rise in the ${ }^{\mathrm{XRF}} \mathrm{Ca}$ content is noted in the second part of HE3, coeval with two minor peaks in magnetic concentration. However, ${ }^{\mathrm{XRF}} \mathrm{Ca}$ values remain under previous GI values. As already introduced for HE4, it is possible that such a rise characterises LIS preferentially detrital-sourced material advection. Bond et al. (1992) hypothesised warmer SSTs in the North Atlantic during HE3, leading to an accelerated melting of icebergs, which thus cannot fully reach the eastern basins of the North Atlantic. This longitudinal "barrier" was also mentioned by Hemming (2004). If so, the late arrival of this collapse from the North American ice sheets could have led to further destabilization of the European ice sheets (second peak recorded by proxies at the transition to GI4).

From the end of HE3, some changes are taking place. Sea-surface conditions seem to record higher amplitude changes between GIs and GSs, as shown for example in the 


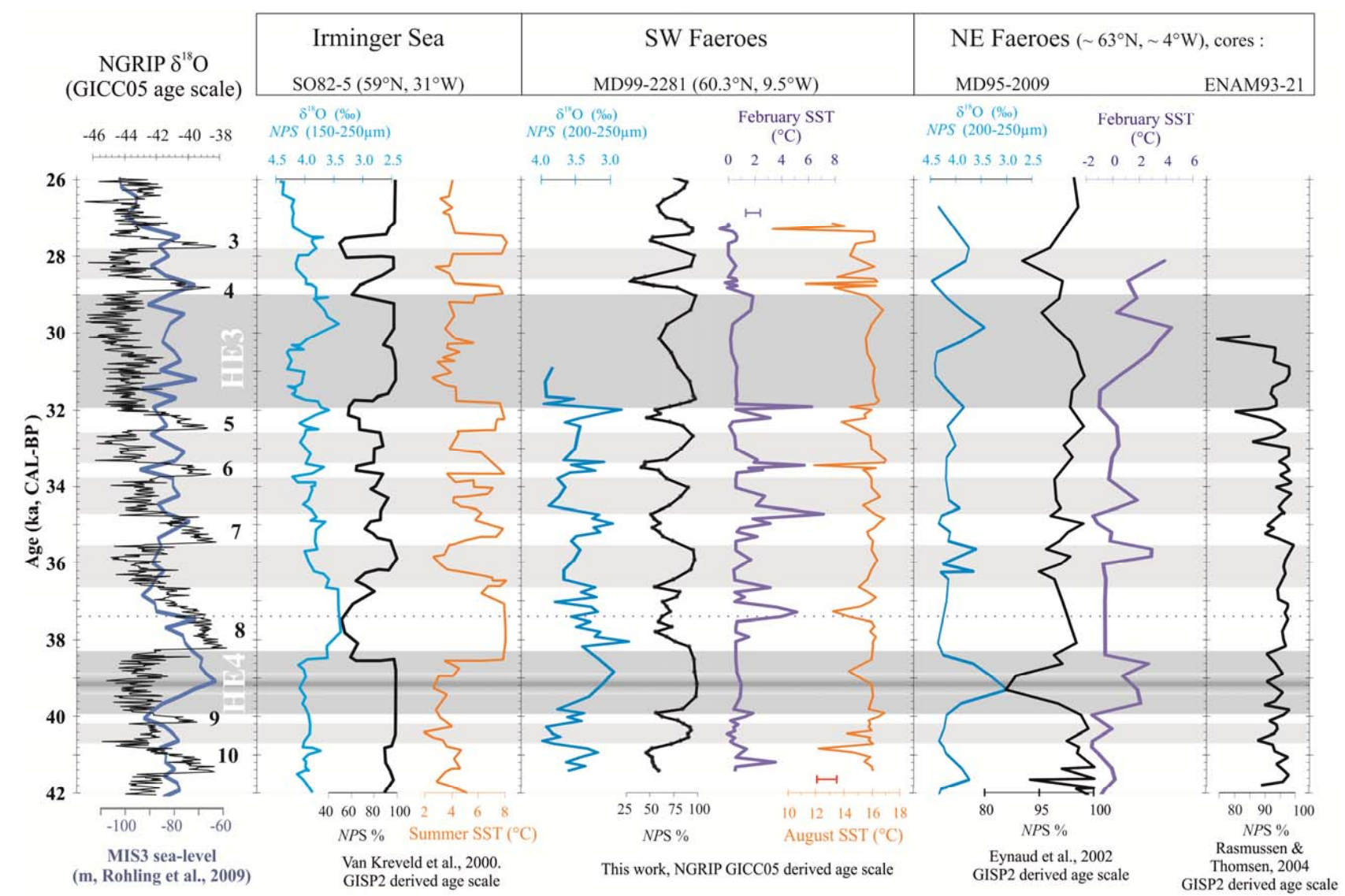

Fig. 7. Compilation of comparable MIS3 marine records from the subpolar North Atlantic (see Fig. 1 for the location of the cores), including core SO82-5 (Van Kreveld et al., 2000), core MD99-2281 (this work), core MD95-2009 (Eynaud et al., 2002) and core ENAM93-21 (Rasmussen and Thomsen, 2004). Proxies from the same nature are shown with the same colour. A reconstruction of the MIS3 sea-level (m) is also shown on the left (Rohling et al., 2009; Siddall et al., 2006). Grey bands: same legend as Fig. 6.

percentages of NPS or in the MS record. This is also attested by the reconstructed SSTs with extreme oscillations recorded in August and in the sea-ice duration as well.

\section{Heterogeneity of the climatic response of the North Atlantic basin during MIS3}

Our dataset constitutes one of the first multiproxy datasets detailing MIS3 sea-surface paleoenvironments south of the Norwegian Sea. Some detailed reconstructions of MIS3 exist further north or further south (e.g. Rasmussen et al., 1996a,b, 1997, 2002a,b; Rasmussen and Thomsen, 2004, 2008) but only a few have been using the same multiproxy approach. Figure 7 tentatively compiles high resolution MIS3 data comparable to the dataset generated for MD99-2281. Despite some differences in the chronology (compiled records other than MD99-2281 derive from the GISP2 chronology) and resolution, it illustrates hydrographical gradients, and thus zonal responses within the same subboreal latitudinal band.
MD99-2281 reconstructions could be compared to those previously produced by Eynaud et al. (2002), who used the same set of proxies in two marine cores retrieved from the southern Norwegian Sea (north of the Faeroe Islands - MD95-2009 and on the Voring plateau - MD95-2010, Fig. 1). Intriguingly, Eynaud et al. (2002) observed an antiphase between sea-surface paleoenvironments (sea ice cover duration, February SST) of the Norwegian Sea and the GIs/GSs atmospheric conditions registered above Greenland (e.g. Dansgaard et al., 1993). Their records demonstrated the establishment of low February SSTs accompanied by a longer sea-ice cover duration in the Norwegian Sea during GIs, whereas the Greenland ice-records testify warm interstadial atmospheric conditions (and vice-versa during GSs, see Fig. 7). According to Eynaud et al. (2002), this paradox pointed to a decoupling between the North Atlantic eastern and western parts during MIS3, involving past climatic phenomena comparable to the modern North Atlantic Oscillation ("Greenland above/Oslo below normal", e.g. Bromwich et al., 1999). 
Low concentrations of IRD were observed by these authors during HE4, in sharp contrast with what was observed in the temperate North Atlantic (e.g. Cortijo et al., 1997; Hemming, 2004). It further suggests isolation of the Norwegian Sea in terms of response to the climatic variability.

Similar results were obtained by de Vernal et al. (2000, 2001, 2005, 2006) for the Nordic Seas with positive SST anomalies (SST above the modern ones) detected during the Last Glacial Maximum. The reconstructed August SSTs on core MD99-2281 during MIS3 show comparable positive anomalies (up to $4{ }^{\circ} \mathrm{C}$ ) dominating the whole studied period (Fig. 5). These observations could be due to peculiar oceanic conditions developing during MIS3 and strongly related to the dynamics of the proximal ice-sheets. A strong stratification of the water column could have been favoured by partial melting of the ice sheets and thus advection of fresh waters, preferentially during summers. The existence of a strong stratification could justify a rapid warming of "a brackish superficial water lens" generating such an anomaly.

The anomalous August SSTs testified a "Norwegian Sea type response" for the summer months (see Eynaud et al., 2002). Late increases of February SST during each GIs furthermore underline some kind of inertia in the sea-surface response of the southern Faeroe domain, thus arguing for a potential influence of the Norwegian sector. However, the high concentrations of IRD observed in core MD99-2281 during HE4 (Fig. 6) suggest that our site also responds synchronously to the temperate North Atlantic, and is thus outside the paradoxical "Nordic Seas" type response.

GI6, 5 and 4 are also paradoxically marked by a higher sea-ice cover duration roughly in antiphase with the percentages of NPS. The same anomaly is observed in the northern core MD95-2010 where interstadial phases over Greenland correspond to a longer sea-ice cover development (Eynaud et al., 2002). We can suggest that from GI6 to GI3, the conditions are so drastic, with proximal European ice sheets reaching their critical maximum size that "our region adopts the same behaviour as the Nordic seas do". The IRD signal recorded in core MD99-2281 during these last GIs could thus correspond to the one also recorded in core MD95-2010 and could therefore be related to the destabilization of the FIS. It is also worth noting that the ice cover in core MD95-2010 varies between 5 and 8 months/year for the GIs, while our core does not record an ice cover exceeding 2 months/year during the whole MIS3. It is conceivable however that from GI6, a change in the local sea-surface conditions may have been initiated due to the gradual development of the proximal ice-sheets.

\section{The role of European ice sheets on proximal sea-surface paleoenvironments during MIS3}

\subsection{Ice-sheet dynamics: the MIS3 marine record}

In the Faeroe Island area, arrivals of detrital material (IRD) to the ocean were interpreted as proximal European ice sheets sourced: their record throughout MIS3 is continuous and highly sensitive to millennial climatic variability as shown by our data and also by previous studies in the same sector (e.g. Scourse et al., 2009; Hibbert et al., 2010; Chiverell and Thomas, 2010; Hall et al., 2011). Continental data from the proximal British Isles have shown "ice-free" conditions during MIS3, as well as in central Scotland, Northern Ireland and the Isle of Man. The BIIS extension was then reduced in latitude at that time and mainly located in the north of Scotland, probably with an advance northward and northwestward (Scourse et al., 2009; Chiverell and Thomas, 2010). This configuration could have promoted the development of an ice shelf, feeding a quite constant icebergs calving and contributing to the observed IRD input record in the area. It is not possible from our data to pinpoint the exact source of IRD; however, the large size of the FIS compared to the British one suggests a preferential Fennoscandian source for IRD. Nevertheless, Hall et al. (2011) pointed to a major BIIS contribution in IRD fluxes recorded in core MD04-2829CQ. This latter being located only $100 \mathrm{~km}$ (nearly one degree in latitude) southward of core MD99-2281 (Figs. 1 and 8), and furthermore responding in the same way during GSs, i.e. recording higher IRD concentrations, it is thus likely that BIIS derived products may also have reached the site of core MD99-2281.

\subsection{The MIS3/MIS2 transition}

The MIS3 termination and the beginning of MIS2 are worth discussion considering our results. Indeed, changes are taking place at the transition between HE3 and GI4 at 28.9 cal ka BP where alternating GIs/GSs sea-surface conditions seem to be more extreme, with marked shifts in SSTs (August especially) and in the sea-ice cover duration. Generally, the MIS3 to MIS2 transition marks conditions that seem progressively more severe in the area, also registering higher instability. Even if only observed in the last $2000 \mathrm{yr}$ of the sequence, it is clearly expressed throughout all our proxies and could be due to growing European ice sheets, with maybe the development of ice shelves on the continental shelf. In fact, the maximum ice volume, which marks the Last Glacial Maximum between 19 and 23 cal ka BP (sensu Mix et al., 2001), does not necessarily correspond to the maximum geographical extension of each ice sheet, which also evolved independently (e.g. Chiverrell and Thomas, 2010). Indeed, some previous studies have suggested that the BIS advanced between 30 and $25 \mathrm{cal} \mathrm{ka} \mathrm{BP.} \mathrm{Hibbert} \mathrm{et}$ al. (2010) show that the core MD04-2822 (Fig. 8), located 


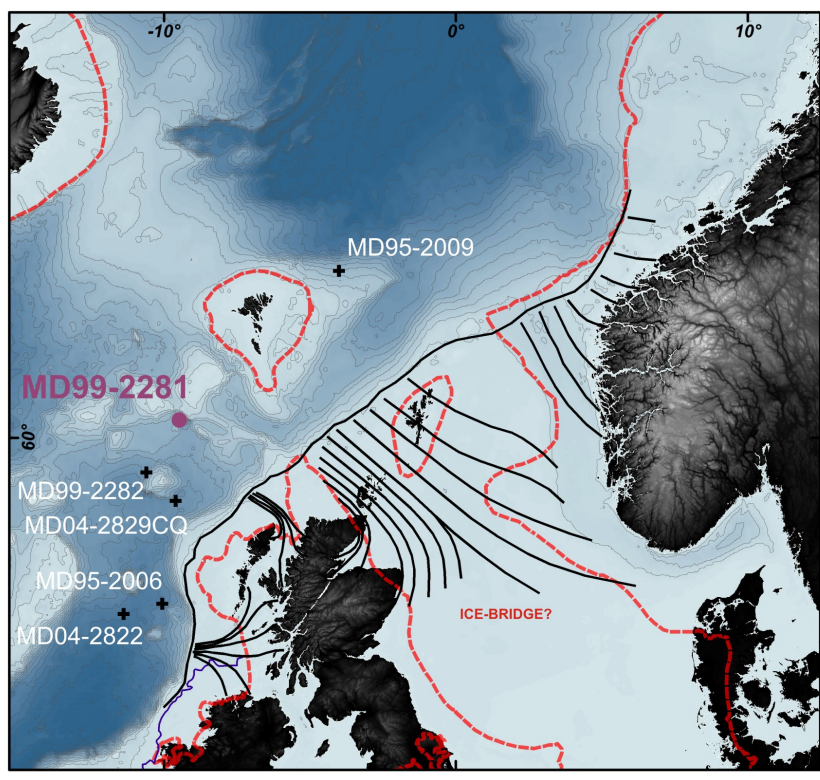

Fig. 8. BIIS-FIS ice sheets and their associated paleo-ice-stream main directions (black solid line, Bradwell et al., 2008). The full glacial extension of the North Hemispheric ice sheets is schematized by the red dotted-line (Grosswald and Hughes, 2002); Ehlers and Gibbard, 2004). Palaeo-coastline at $21 \mathrm{ka} \mathrm{BP}$ in blue (Bourillet et al., 2003). The studied core (MD99-2281: this work) and other cores discussed in the paper (MD95-2009; Eynaud et al., 2002; MD04-2822; MD95-2006; Knutz et al., 2001; Hibbert et al., 2010; MD04-2829CQ; Hall et al., 2011) are also located.

west of the Barra-Donegal Fan, has recorded an increase in IRD at $27.4 \mathrm{cal} \mathrm{kaBP}$. The same is observed by Hall et al. (2011) in core MD04-2829CQ, located southeast of the Rosemary Bank, pointing to an increase of the BIIS size after $\sim 28$ ka BP. Similarly, Knutz et al. (2001) observed in core MD95-2006 (Fig. 8), located in the heart of Barra-Donegal Fan, increases of IRD concentrations (coming from the Tertiary basaltic provinces involving a British source) at about $30 \mathrm{ka}$, which coincide with the MIS3/MIS2 transition (Hibbert et al., 2010). Scourse et al. (2009) also illustrate an advance in the west of the British ice sheet (BIS) at the Bench level and Rosemary Barra-Donegal Fan just after HE3, at about $29 \mathrm{ka}$. IRD concentration increases at $27 \mathrm{ka}$ on the Irish western margin and at $25 \mathrm{ka}$ on the Goban Spur, characterising a progressive southward ice-sheet development (Scourse et al., 2009). This progression also affected the northeastern British ice margin. Actually, geomorphological studies conducted in the North Sea Basin and Norwegian Channel (Bradwell et al., 2007, 2008) have suggested confluent Bristish and Fennoscandian ice sheets during this period. This coalescence associated to a major paleo-ice-stream system purging the "ice-bridge" (Fig. 8, Bradwell et al., 2008) might have alimented one of the most important ice shelves of the European margin. Core MD99-2281, which is located in the axis of two of these ice streams (Fig. 8, Bradwell et al.,
2008), the Minch paleo-ice stream and the North Sea paleoice stream, may have thus recorded destabilizations of this system.

\section{Conclusions}

The present multiproxy study, conducted on the MIS3 section of core MD99-2281 located off SW Faeroes, provides a new and unique set of data, expanding our knowledge about the evolution of NW Europe oceanic palaeoenvironments during the last glacial. Our results demonstrate that the marine reservoir echoes directly to the rapid climate changes detected in the atmosphere (Greenland $\delta^{18} \mathrm{O}$ records). Deepsea parameters (deduced from magnetic properties) show the same general pattern as along the main path of the NADW in the subpolar North Atlantic (e.g. Kissel et al., 1999a). These parameters were therefore used to tie the surface multi-proxy records on the millennial climatic variability that characterises the MIS3. Results demonstrate that the surface oceanic response of the area was strongly influenced by the dynamics of the proximal ice sheets. Data identify a much more important calving of European ice sheets during GSs and milder conditions during GIs, with however late and terminal warmings (rather occurring at the transition towards GSs). Large amounts of detrital material (including IRD) are recovered for each GSs and are likely to have a European origin, and more precisely a BIS source. Sea-surface paleoenvironmental conditions during HEs are quite similar to those recorded during other GSs, except for some indices of a probable larger Laurentide influence (both within HE4 and HE3).

Marked paleoenvironmental changes seem to occur after 28.9 cal ka BP (post-HE3 record). This reinforces previous findings which hypothesise the existence of an ice bridge between the British and the Fennoscandian ice sheets, which would have potentially directly influenced our site of study after HE3. The coalescence of the FIS and BIS could have fed an ice shelf proximal to the site of core MD99-2281; the high variability of sea-surface palaeoenvironments detected in our data could support the presence of such a structure. This implies that the glacial advance of the British ice sheet toward its maximum extension was probably reached before the Last Glacial Maximum. Further studies are needed to better constrain this late history of the British ice sheet and its relation to the dynamics of its surrounding ice shelves.

Acknowledgements. The authors are grateful to IPEV, the captain and the crew of the Marion-Dufresne and the scientific team of the GINNA cruise (Labeyrie et al., 1999). We wish to thank Y. Balut for his assistance at sea. J. St Paul, O. Ther, M.-H. Castera and $\mathrm{M}$. Georget provided invaluable technical assistance. We acknowledge financial support by the ARTEMIS ${ }^{14} \mathrm{C}$ Accelerator Mass Spectrometry French project. Part of the analyses conducted on MD99-2281 was supported by the French INSU (Institut 
National des Sciences de l'Univers) program LEFE/EVE (Les enveloppes fluides et l'environnement/Evolution et variabilité du climat à l'échelle globale) "RISCC: Rôle des Ice-Shelves dans le Changement Climatique". The magnetic analyses at LSCE were made with the help of Camille Wandres from laboratory funds from the French Atomic Energy Commission and from the CNRS. This is an U.M.R./EPOC 5805 (Université Bordeaux I - C.N.R.S.) contribution.

Edited by: M. Siddall

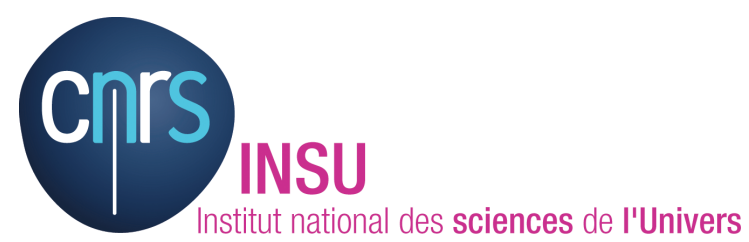

The publication of this article is financed by CNRS-INSU.

\section{References}

Alley, R. B., Clark, P. U., Keigwin, L. D., and Webb, R. S.: Making sense of millennial-scale climate change, in: Mechanisms of global climate change at millennial time scales, edited by: Clark, P. U., Webb, R. S., and Keigwin, L. D., Geophys. Monogr., 385394, 1999.

Alvarez-Solas, J., Charbit, S., Ritz, C., Paillard, D., Ramstein, G., and Dumas, C.: Links between ocean temperature and iceberg discharge during Heinrich events, Nat. Geosci., 3, 122-126, 2010.

Auffret, G. A., Boelaert, A., Vergnaud-Grazzini, C., Müller, C., and Kerbrat, R.: Identification of Heinrich layers in core ks 01 northeastern Atlantic $\left(46^{\circ} \mathrm{N}, 17^{\circ} \mathrm{W}\right)$, implications for their origin, Mar. Geol., 131, 5-20, 1996.

Austin, W. E. N. and Hibbert, F. D.: Tracing time in the ocean: A brief review of chronological constraints (60-8 kyr) on north atlantic marine event-based stratigraphies, Quaternary Sci. Rev., 36, 28-37, 2012.

Ballini, M., Kissel, C., Colin, C., and Richter, T.: Deepwater mass source and dynamic associated with rapid climatic variations during the last glacial stage in the north Atlantic: a multi-proxy investigation of the detrital fraction of deep-sea sediments, Geochem. Geophy. Geosy., 7, Q02N01, doi:10.1029/2005GC001070, 2006.

Bard, E.: Geochemical and geophysical implications of the radiocarbon calibration, Geochim. Cosmochim. Acta, 62, 2025-2038, 1998.

Bard, E., Arnold, M., Hamelin, B., Tisnerat-Laborde, N., and Cabioch, G.: Radiocarbon calibration by means of mass spectrometric ${ }^{230} \mathrm{Th} /{ }^{234} \mathrm{U}$ and ${ }^{14} \mathrm{C}$ ages of corals. An updated data base including samples from Barbados, Mururoa and Tahiti, Radiocarbon, 40, 1085-1092, 1998.

Berger, A.: Les causes astronomiques des grandes variations du climat au Quaternaire, C. R. Palevol., 5, 21-26, 2006.

Bett, B. J.: UK atlantic margin environmental survey: introduction and overview of bathyal benthic ecology, Cont. Shelf Res., 21, 917-956, 2001.
Bogus, K. A., Zonneveld, K. A. F., Fischer, D., Kasten, S., Bohrmann, G., and Versteegh, G. J. M.: The effect of meter-scale lateral oxygen gradients at the sediment-water interface on selected organic matter based alteration, productivity and temperature proxies, Biogeosciences, 9, 1553-1570, doi:10.5194/bg-91553-2012, 2012.

Boldreel, L. O., Andersen, M. S., and Kuijpers, A.: Neogene seismic facies and deep-water gateways in the faeroe bank area, ne atlantic, Mar. Geol., 152, 129-140, 1998.

Bond, G. and Lotti, R.: Iceberg discharges into the north Atlantic on millennial time scales during the last glaciation, Science, 267, 1005-1010, 1995.

Bond, G., Heinrich, H., Broecker, W., Labeyrie, L., McManus, J., Andrews, J., Huon, S., Jantschik, R., Clasen, S., Simet, C., Tedesco, C., Klas, M., Bonani, G., and Ivy, S.: Evidence for massive discharges of icebergs into the north Atlantic ocean during the last glacial period, Nature, 360, 246-249, 1992.

Bond, G., Broecker, W., Johnsen, S., McManus, J., Labeyrie, L., Jouzel, J., and Bonani, G.: Correlations between climate records from North Atlantic sediments and Greenland ice, Nature, 365, 143-147, 1993.

Boulay, S.: Variabilité climatique rapide en atlantique nord - un potentiel de réponses: La carotte MD99-2281 (sud des îles faeroes), MASTER Université Paris-Sud, Orsay, 2000.

Bourillet, J.-F., Reynaud, J. Y., Baltzer, A., and Zaragosi, S.: The "fleuve manche": The sub-marine sedimentary features from the outer shelf to the deep-sea fans, J. Quaternay Sci., 18, 261-282, 2003.

Brachfeld, S., Kissel, C., Laj, C., and Mazaud, A.: Behavior of u-channels during acquisition and demagnetization of remanence: Implications for paleomagnetic and rock-magnetic measurements, Phys. Earth Planet. Int., 145, 1-8, 2004.

Bradwell, T., Stoker, M., and Larter, R.: Geomorphological signature and flow dynamics of the minch palaeo-ice stream, northwest Scotland, J. Quaternary Sci., 22, 609-617, 2007.

Bradwell, T., Stoker, M., Golledge, N. R., Wilson, C. K., Merritt, J. W., Long, D., Everest, J. D., Hestvik, O. B., Stevenson, A. G., Hubbard, A. L., Finlayson, A. G., and Mathers, H. E.: The northern sector of the last British ice sheet: Maximum extent and demise, Earth-Sci. Rev., 88, 207-226, 2008.

Broecker, W. S.: Thermohaline circulation, the Achilles heel of our climate system: Will man-made co2 upset the current balance?, Science, 278, 1582-1588, 1997.

Broecker, W. S.: Does the trigger for abrupt climate change reside in the ocean or in the atmosphere?, Science, 300, 1519-1522, 2003.

Bromwich, D. H., Chen, Q.-S., Li, Y., and Cullather, R. I.: Precipitation over Greenland and its relation to the north Atlantic oscillation, J. Geophys. Res., 104, 22103-22115, 1999.

Chiverrell, R. C. and Thomas, G. S. P.: Extent and timing of the last glacial maximum (LGM) in Britain and Ireland: A review, J. Quaternary Sci., 25, 535-549, 2010.

Clark, P. U., Pisias, N. G., Stocker, T. F., and Weaver, A. J.: The role of the thermohaline circulation in abrupt climate change, Nature, 415, 863-869, 2002.

Cortijo, E., Labeyrie, L., Vidal, L., Vautravers, M., Chapman, M., Duplessy, J. C., Elliot, M., Arnold, M., Turon, J. L., and Auffret, G. A.: Changes in sea surface hydrology associated with Heinrich event 4 in the north Atlantic ocean between $40^{\circ}$ and $60^{\circ} \mathrm{N}$, Earth Planet. Sc. Lett., 146, 29-45, 1997. 
Dansgaard, W., Johnsen, S. J., Clausen, H. B., Dahl-Jengen, D., Gundestrup, N. S., Hammer, C. U., Hvidberg, C. S., Steffensen, J. P., Sveinbjörnsdottir, A. E., Jouzel, J., and Bond, G.: Evidence for general instability of past climate from 250-kyr ice-core record, Nature, 364, 218-220, 1993.

De Leeuw, J. W., Versteegh, G. J. M., and Van Bergen, P. F.: Biomacromolecules of algae and plants and their fossil analogues, Plant Ecol., 182, 209-233, 2006.

de Vernal, A.: Dino8 workshop: Quantitative treatments for paleoceanographical reconstructions based on dinocyst assemblages, Dino8 conference, Montréal, 2008.

de Vernal, A. and Marret, F.: Chapter nine : Organic-walled dinoflagellate cysts: tracers of sea-surface conditions, in: Developments in marine geology, edited by: Hillaire-Marcel, C. and de Vernal, A., Elsevier, 371-408, 2007.

de Vernal, A. and Rochon, A.: Dinocysts as tracers of sea-surface conditions and sea-ice cover in polar and subpolar environments, IOP Conference Series: Earth and Environmental Science, 2011.

de Vernal, A., Henry, M., and Bilodeau, G.: Techniques de préparation et d'analyse en micropaléontologie, Les cahiers du GEOTOP, 3, 1-29, 1996.

de Vernal, A., Hillaire-Marcel, C., Turon, J. L., and Matthiessen, J.: Reconstruction of sea-surface temperature, salinity, and seaice cover in the northern north Atlantic during the last glacial maximum based on dinocyst assemblages, Can. J. Earth Sci., 37, 725-750, 2000.

de Vernal, A., Henry, M., Matthiessen, J., Mudie, P. J., Rochon, A., Boessenkool, K. P., Eynaud, F., Grãsfjeld, K., Guiot, J., Hamel, D., Harland, R., Head, M. J., Kunz-Pirrung, M., Levac, E., Loucheur, V., Peyron, O., Pospelova, V., Radi, T., Turon, J. L., and Voronina, E.: Dinoflagellate cyst assemblages in surface sediments of the Laptev sea region (Arctic Ocean) and their relationship to hydrographic conditions, J. Quaternary Sci., 16, 637649, 2001.

de Vernal, A., Eynaud, F., Henry, M., Hillaire-Marcel, C., Londeix, L., Mangin, S., Matthiessen, J., Marret, F., Radi, T., Rochon, A., Solignac, S., and Turon, J. L.: Reconstruction of sea-surface conditions at middle to high latitudes of the northern hemisphere during the last glacial maximum (LGM) based on dinoflagellate cyst assemblages, Quaternary Sci. Rev., 24, 897-924, 2005.

de Vernal, A., Rosell-Melé, A., Kucera, M., Hillaire-Marcel, C., Eynaud, F., Weinelt, M., Dokken, T., and Kageyama, M.: Comparing proxies for the reconstruction of LGM sea-surface conditions in the northern north Atlantic, Quaternary Sci. Rev., 25, 28202834, 2006.

Dickson, R. R., Meincke, J., Malmberg, S.-A., and Lee, A. J.: The "Great salinity anomaly" in the northern north Atlantic 19681982, Prog. Oceanogr., 20, 103-151, 1988.

Ehlers, J. and Gibbard, P.: Quaternary glaciations - extent and chronology part I: Europe, in: Developments in quaternary science, no. 2, Publisher Elsevier, Amsterdam, p. 488, 2004.

Elliot, M., Labeyrie, L., Dokken, T., and Manthe, S.: Coherent patterns of ice-rafted debris deposits in the Nordic regions during the last glacial (10-60 ka), Earth Planet. Sc. Lett., 194, 151-163, 2001.

Ericson, D. B.: Coiling direction of Globigerina pachyderma as a climatic index, Science, 130, 219-220, 1959.
Evitt, W. R.: Sporopollenin dinoflagellate cysts: their morphology and interpretation, AASP Foundation - American Association of Stratigraphic Palynologists, Dallas, 1985.

Eynaud, F.: Kystes de dinoflagellés et evolution paléoclimatique et paléohydrologique de l'atlantique nord au cours du dernier cycle climatique du quaternaire, Université de Bordeaux I, 291 pp., 1999.

Eynaud, F., Turon, J. L., Matthiessen, J., Kissel, C., Peypouquet, J. P., De Vernal, A., and Henry, M.: Norwegian sea-surface palaeoenvironments of marine oxygen-isotope state 3: the paradoxical response of dinoflagellate cysts, J. Quaternary Sci., 17, 349-359, 2002.

Eynaud, F., Zaragosi, S., Scourse, J. D., Mojtahid, M., Bourillet, J. F., Hall, I. R., Penaud, A., Locascio, M., and Reijonen, A.: Deglacial laminated facies on the NW European continental margin: The hydrographic significance of British-Irish Ice Sheet deglaciation and Fleuve Manche paleoriver discharges, Geochem. Geophy. Geosy., 8, Q06019, doi:10.1029/2006GC001496, 2007.

Eynaud, F., De Abreu, L., Voelker, A., Schönfeld, J., Salgueiro, E., Turon, J. L., Penaud, A., Toucanne, S., Naughton, F., Sanchez Goni, M. F., Malaizé, B., and Cacho, I.: Position of the polar front along the western Iberian margin during key cold episodes of the last $45 \mathrm{ka}$, Geochem. Geophy. Geosy., 10, Q07U05, doi:10.1029/2009GC002398, 2009.

Eynaud, F., Malaizé, B., Zaragosi, S., de Vernal, A., Scourse, J., Pujol, C., Cortijo, E., Grousset, F. E., Penaud, A., Toucanne, S., Turon, J. L., and Auffret, G.: New constraints on European glacial freshwater releases to the North Atlantic Ocean, Geophys. Res. Lett., 39, L15601, doi:10.1029/2012GL052100, 2012.

Fogelqvist, E., Blindheim, J., Tanhua, T., Østerhus, S., Buch, E., and Rey, F.: Greenland-Scotland overflow studied by hydro-chemical multivariate analysis, Deep-Sea Res. Pt. I, 50, 73-102, 2003.

Grosswald, M. G. and Hughes, T. J.: The russian component of an arctic ice sheet during the last glacial maximum, Quaternary Sci. Rev., 21, 121-146, 2002.

Grousset, F., Pujol, C., Labeyrie, L., Auffret, G. A., and Boelaert, A.: Were the North Atlantic Heinrich events triggered by the behavior of the European ice sheet?, Geology, 28, 123-126, 2000.

Grousset, F. E., Cortijo, E., Huon, S., Hervé, L., Richter, T., Burdloff, D., Duprat, J., and Weber, O.: Zooming in on Heinrich layers, Paleoceanography, 16, 240-259, 2001.

Grützner, J. and Higgins, S. M.: Threshold behavior of millennial scale variability in deep water hydrography inferred froma $1.1 \mathrm{Ma}$ long record of sediment provenance at the southern Gardar Drift, Paleoceanography, 25, PA4204, doi:10.1029/2009PA001873, 2010.

Guiot, J. and de Vernal, A.: Chapter thirteen transfer functions: Methods for quantitative paleoceanography based on microfossils, in: Developments in marine geology, edited by: HillaireMarcel, C. and de Vernal, A., Elsevier, Amsterdam, 523-563, 2007.

Guiot, J. and de Vernal, A.: Is spatial autocorrelation introducing biases in the apparent accuracy of paleoclimatic reconstructions?, Quaternary Sci. Rev., 30, 1965-1972, 2011a.

Guiot, J. and de Vernal, A.: QSR correspondence "Is spatial autocorrelation introducing biases in the apparent accuracy of palaeoclimatic reconstructions?" Reply to Telford and Birks, Quaternary Sci. Rev., 30, 3214-3216, 2011 b. 
Hall, I. R., E. Colmenero-Hidalgo, R. Zahn, V. L. Peck, and S. R. Hemming: Centennial- to millennial-scale ice-ocean interactions in the subpolar northeast Atlantic 18-41 kyr ago, Paleoceanography, 26, PA2224, doi:10.1029/2010PA002084, 2011.

Harland, R.: Distribution maps of recent dinoflagellate cysts in bottom sediments from the north Atlantic Ocean and adjacent seas, Palaeontology, 26, 321-387, 1983.

Heinrich, H.: Origin and consequences of cyclic ice rafting in the northeast Atlantic Ocean during the past 130,000 years, Quaternary Res., 29, 142-152, 1988.

Hemming, S. R.: Heinrich events: massive late Pleistocene detritus layers of the north Atlantic and their global climate imprint, Rev. Geophys., 42, 1001-1043, 2004.

Hibbert, F. D., Austin, W. E. N., Leng, M. J., and Gatliff, R. W.: British ice sheet dynamics inferred from north Atlantic ice-rafted debris records spanning the last 175000 years, J. Quaternary Sci., 25, 461-482, 2010.

Hodell, D. A., Channell, J. E. T., Curtis, J. H., Romero, O. E., and Röhl, U.: Onset of "Hudson Strait" Heinrich events in the eastern North Atlantic at the end of the middle Pleistocene transition $(\sim 640 \mathrm{ka})$ ?, Paleoceanography, 23, PA4218, doi:10.1029/2008PA001591, 2008.

Holliday, N. P., Pollard, R. T., Read, J. F., and Leach, H.: Water mass properties and fluxes in the Rockall trough, 1975-1998, DeepSea Res. Pt. I, 47, 1303-1332, 2000.

Howe, J. A., Stoker, M. S., Masson, D. G., Pudsey, C. J., Morris, P., Larter, R. D., and Bulat, J.: Seabed morphology and the bottom-current pathways around rosemary bank seamount, northern Rockall trough, north Atlantic, Mar. Petrol. Geol., 23, 165-181, 2006.

Hulbe, C. L., MacAyeal, D. R., Denton, G. H., Kleman, J., and Lowell, T. V.: Catastrophic ice shelf breakup as the source of Heinrich event icebergs, Paleoceanography, 19, 711-717, 2004.

Imbrie, J., Berger, A., Boyle, E. A., Clemens, S. C., Duffy, A., Howard, W. R., Kukla, G., Kutzbach, J., Martinson, D. G., McIntyre, A., Mix, A. C., Molfino, B., Morley, J. J., Peterson, L. C., Pisias, N. G., Prell, W. L., Raymo, M. E., Shackleton, N. J., and Toggweiler, J. R.: On the structure and origin of major glaciation cycles: 2 . The 100,000 year cycle, Paleoceanography, 8, 699735, 1993.

Jonkers, L., Moros, M., Prins, M. A., Dokken, T., Andersson Dahl, C., Dijkstra, N., Perner, K., and Brummer, G.-J. A.: A reconstruction of sea surface warming in the northern north Atlantic during MIS3 ice-rafting events, Quaternary Sci. Rev., 29, 1791-1800, 2010a.

Jonkers, L., Brummer, G. J. A., and De Jong, M. F.: Seasonal stratification, shell flux, and oxygen isotope dynamics of left coiling $N$. pachyderma and T. quinqueloba in the western subpolar north Atlantic, Paleoceanography, 25, PA2204, doi:10.1029/2009PA001849, 2010b.

Kiefer, T., Lorenz, S., Schulz, M., Lohmann, G., Sarnthein, M., and Elderfield, H.: Response of precipitation over Greenland and the adjacent ocean to the north pacific warm spells during Dansgaard-Oeschger stadials, Terra Nova, 14, 295-300, 2002.

Kissel, C., Laj, C., Labeyrie, L., Dokken, T., Voelker, A., and Blamart, D.: Rapid climatic variations during marine isotopic stage 3: Magnetic analysis of sediments from Nordic seas and north Atlantic, Earth Planet. Sc. Lett., 171, 489-502, 1999a.
Kissel, C., Laj, C., Labeyrie, L., Dokken, T., Voelker, A., and Blamart, D.: Magnetic signature of rapid climatic variations in North Atlantic sediments, in: Reconstructing Ocean History: A Window Into the Future, edited by: Abrantes, F. and Mix, A., Springer, New York, 419-437, 1999b.

Knutz, P. C., Austin, W. E. N., and Jones, E. J. W.: Millennialscale depositional cycles related to British ice sheet variability and north Atlantic paleocirculation since 45 kyr B.P., Barra fan, U.K. Margin, Paleoceanography, 16, 53-64, 2001.

Kucera, M.: Chapter six: planktonic foraminifera as tracers of past oceanic environments, in: Developments in Marine Geology, Elsevier, Amsterdam, 213-262, 2007.

Kucera, M., Rosell-Melé, A., Schneider, R., Waelbroeck, C., and Weinelt, M.: Multiproxy approach for the reconstruction of the glacial ocean surface (MARGO), Quaternary Sci. Rev., 24, 813819, 2005.

Kuijpers, A., Andersen, M. S., Kenyon, N. H., Kunzendorf, H., and van Weering, T. C. E.: Quaternary sedimentation and Norwegian sea overflow pathways around bill bailey bank, northeastern Atlantic, Mar. Geol., 152, 101-127, 1998.

Kuijpers, A., Hansen, B., Huhnerbach, V., Larsen, B., Nielsen, T., and Werner, F.: Norwegian sea overflow through the FaroeShetland gateway as documented by its bedforms, Mar. Geol., 188, 147-164, 2002.

Labeyrie, L., Cortijo, E., and Jansen, E.: Rapport scientifique de la mission INTERPOLE MD99-114/812 IMAGES V, Brest, 1999.

Laj, C., Kissel, C., Mazaud, A., Channell, J. E. T., and Beer, J.: North Atlantic Paleointensity Stack since $75 \mathrm{ka}$ (NAPIS-75) and the duration of the Laschamp event, Philos. T. Roy. Soc. Lond., 358, 1009-1025, 2000.

Lang, C., Leuenberger, M., Schwander, J., and Johnsen, S.: $16^{\circ} \mathrm{C}$ rapid temperature variation in central Greenland 70,000 years ago, Science, 1286, 934-937, 1999.

Larsen, K. M. H., Hansen, B., and Svendsen, H.: Faroe shelf water, Cont. Shelf Res., 28, 1754-1768, 2008.

Larsen, K. M. H., Hansen, B., and Svendsen, H.: The Faroe shelf front: Properties and exchange, J. Mar. Syst., 78, 9-17, 2009.

Lericolais, G., Auffret, J.-P., and Bourillet, J.-F.: The Quaternary Channel River: seismic stratigraphy of its palaeo-valleys and deeps, J. Quaternary Sci., 18, 245-260, 2003.

Marret, F. and Zonneveld, K. A. F.: Atlas of modern organic-walled dinoflagellate cyst distribution, Rev. Palaeobot. Palynol., 125, 1200, 2003.

Martinson, D. G., Pisias, N. G., Hays, J. D., Imbrie, J., Moore Jr., T. C., and Shackleton, N. J.: Age dating and the orbital theory of the ice ages: Development of a high-resolution 0 to 300,000-year chronostratigraphy, Quaternary Res., 27, 1-29, 1987.

Masson, D. G., Howe, J. A., and Stoker, M. S.: Bottom-current sediment waves, sediment drifts and contourites in the northern Rockall trough, Mar. Geol., 192, 215-237, 2002.

Matthiessen, J., Kunz-Pirrung, M., and Mudie, P. J.: Freshwater chlorophycean algae in recent marine sediments of the Beaufort, Laptev and Kara seas (Arctic ocean) as indicators of river runoff, Int. J. Earth Sci., 89, 470-485, 2000.

Ménot, G., Bard, E., Rostek, F., Weijers, J. W. H., Hopmans, E. C., Schouten, S., and Sinninghe-Damsté, J. S.: Early reactivation of European rivers during the last deglaciation, Science, 313, 1623$1625,2006$. 
Mertens, K. N., Verhoeven, K., Verleye, T., Louwye, S., Amorim, A., Ribeiro, S., Deaf, A. S., Harding, I., De Schepper, S., Kodrans-Nsiah, M., de Vernal, A., Radi, T., Dybkjaer, K., Poulsen, N. E., Feist-burkhardt, S., Chitolie, J., González Arango, C., Heilmann-Clausen, C., Londeix, L., Turon, J.-L., Marret, F., Matthiessen, J., McCarthy, F. M. G., Prasad, V., Pospelova, V., Kyffin Hughes, J. E., Riding, J. B., Rochon, A., Sangiorgi, F., Welters, N., Sinclair, N., Thun, C., Soliman, A., Van Nieuwenhove, N., Vink, A., and Young, M.: Determining the absolute abundance of dinoflagellate cysts in recent marine sediments: The Lycopodium marker-grain method put to the test, Rev. Palaeobot. Palynol., 157, 238-252, 2009.

Mix, A. E., Bard, E., and Schneider, R.: Environmental processes of the ice age: Land, ocean, glacier (EPILOG), Quaternary Sci. Rev., 20, 627-657, 2001.

Mojtahid, M., Eynaud, F., Zaragosi, S., Scourse, J., Bourillet, J. F., and Garlan, T.: Palaeoclimatology and palaeohydrography of the glacial stages on Celtic and Armorican margins over the last 360000 yrs, Mar. Geol., 224, 57-82, 2005.

New, A. L. and Smythe-Wright, D.: Aspects of the circulation in the Rockall trough, Cont. Shelf Res., 21, 777-810, 2001.

Penaud, A.: Interactions climatiques et hydrologiques du système Méditerranée/Atlantique au Quaternaire, $\mathrm{PhD}$ thesis, Bordeaux, 2009.

Penaud, A., Eynaud, F., Turon, J. L., Zaragosi, S., Malaizé, B., Toucanne, S., and Bourillet, J. F.: What forced the collapse of European ice sheets during the last two glacial periods (150 ka B.P. and 18 ka cal B.P.)? Palynological evidence, Palaeogeogr. Palaeocl., 281, 66-78, 2009.

Platov, G. A.: Numerical modeling of the arctic ocean deepwater formation: Part II. Results of regional and global experiments, Izvestiya, Atmos. Ocean. Phys., 47, 377-392, 2011.

Rahmstorf, S.: Ocean circulation and climate during the past 120,000 years, Nature, 419, 207-214, 2002.

Rasmussen, S. O., Seierstad, I. K., Andersen, K. K., Bigler, M., Dahl-Jansen, D., and Johnsen, S. J.: Synchronization of the NGRIP, GRIP, and GISP2 ice cores across MIS 2 and palaeoclimatic implications, Quaternary Sci. Rev., 27, 18-28, 2008.

Rasmussen, T. L. and Thomsen, E.: The role of the north Atlantic drift in the millennial timescale glacial climate fluctuations, Palaeogeogr. Palaeocl., 210, 101-116, 2004.

Rasmussen, T. L. and Thomsen, E.: Warm Atlantic water inflow to the Nordic seas 34-10 ka calibrated ka BP, Paleoceanography, 23, PA1201, doi:10.1029/2007PA001453, 2008.

Rasmussen, T. L., Vanweering, T. C. E., and Labeyrie, L.: High resolution stratigraphy of the Faeroe-Shetland channel and its relation to north Atlantic paleoceanography: The last $87 \mathrm{kyr}$, Mar. Geol., 131, 75-88, 1996a.

Rasmussen, T. L., Thomsen, E., Vanweering, T. C. E., and Labeyrie, L.: Rapid changes in surface and deep water conditions at the Faeroe margin during the last 58,000 years, Paleoceanography, 11, 757-771, 1996b.

Rasmussen, T. L., Van weering, T. C. E., and Labeyrie, L.: Climatic instability, ice sheets and ocean dynamics at high northern latitudes during the last glacial period (58-10 ka BP), Quaternary Sci. Rev., 16, 71-80, 1997.
Rasmussen, T. L., Thomsen, E., Troelstra, S. R., Kuijpers, A., and Prins, M. A.: Millennial-scale glacial variability versus Holocene stability: Changes in planktic and benthic foraminifera faunas and ocean circulation in the north Atlantic during the last 60000 years, Mar. Micropaleontol., 47, 143-176, $2002 \mathrm{a}$.

Rasmussen, T. L., Bäckström, D., Heinemeier, J., KlitgaardKristensen, D., Knutz, P. C., Kuijpers, A., Lassen, S., Thomsen, E., Troelstra, S. R., and van Weering, T. C. E.: The faroe- shetland gateway: Late quaternary water mass exchange between the nordic seas and the northeastern atlantic, Mar. Geol., 188, 165192, 2002 b.

Richter, T. O., Van Der Gaast, S., Koster, B., Vaars, A., Gieles, R., de Stigter, H. C., de Haas, H., and Van Weering, T. C. E.: The AVAATECH XRF core scanner: Technical description and applications to NE Atlantic sediments, in: New techniques in sediment core analysis, edited by: Rothwell, R. G., Geological Society Special Publications, London, 39-50, 2006.

Roche, D. M., Wiersma, A. P., and Renssen, H.: A systematic study of the impact of freshwater pulses with respect to different geographical locations, Clim. Dynam., 34, 997-1013, 2010.

Rochon, A., de Vernal, A., Turon, J.-L., Matthiessen, J., and Head, M. J.: Recent dinoflagellate cysts of the north Atlantic ocean and adjacent seas in relation to sea-surface parameters, edited by: Ser, A. C., AASP - American Association of Stratigraphic Palynologists, Contrib. Ser., Dallas, 1-152, 1999a.

Rochon, A., de Vernal, A., Turon, J.-L., Matthiessen, J., and Head, M. J.: Distribution of dinoflagellate cysts in surface sediments from the north Atlantic ocean and adjacent basins and quantitative reconstruction of sea-surface parameters, AASP special pub., p. 146, 1999 b.

Rochon, A., Eynaud, F., and de Vernal, A.: Dinocysts as tracers of hydrographical conditions and productivity along the ocean margins: Introduction, Mar. Micropaleontol., 68, 1-5, 2008.

Rohling, E. J., Grant, K., Bolshaw, M., Roberts, A. P., Siddall, M., Hemleben, C., and Kucera, M.: Antarctic temperature and global sea level closely coupled over the past five glacial cycles, Nat. Geosci., 2.7, 500-504, 2009.

Ruddiman, W. F.: Late Quaternary deposition of ice-rafted sand in the subpolar North Atlantic (lat $40^{\circ}$ to $65^{\circ} \mathrm{N}$ ), GSA Bulletin, 88, 1813-1827, 1977.

Sánchez Goñi, M. F. and Harrison, S. P.: Global patterns of vegetation response to millennial-scale variability and rapid climate change during the last glacial period, Quaternary Sci. Rev., 29, 2957-2980, 2010.

Sánchez-Goñi, M. F., Landais, A., Fletcher, W. J., Naughton, F., Desprat, S., and Duprat, J.: Contrasting impacts of dansgaardoeschger events over a western european latitudinal transect modulated by orbital parameters, Quaternary Sci. Rev., 27, 1136-1151, 2008.

Schulz, M.: On the 1470-year pacing of DansgaardOeschger warm events, Paleoceanography, 17, 1014, doi:10.1029/2000PA000571, 2002.

Scourse, J. D., Hall, I. R., McCave, I. N., Young, J. R., and Sugdon, C.: The origin of Heinrich layers: Evidence from $\mathrm{h} 2$ for European precursor events, Earth Planet. Sc. Lett., 182, 187-195, 2000. 
Scourse, J. D., Haapaniemi, A. L., Colmenero-Hidalgo, E., Peck, V. L., Hall, I. R., Austin, W. E. N., Knutz, P. C., and Zahn, R.: Growth, dynamics and deglaciation of the last British-Irish ice sheet: The deep-sea ice rafted detritus record, Quaternary Sci. Rev., 28, 3066-3084, 2009.

Severinghaus, J. P. and Brook, E. J.: Abrupt climate change at the end of the last glacial period inferred from trapped air in polar ice, Science, 286, 930-934, 1999.

Siddall, M. et al.: Red Sea Sea Level Reconstruction, IGBP PAGES/World Data Center for Paleoclimatology Data Contribution Series \# 2006-063, NOAA/NCDC Paleoclimatology Program, Boulder CO, USA. 2006.

Snoeckx, H., Grousset, F. E., Revel, M., and Boelaert, A.: European contribution of ice-rafted sand to Heinrich layers H3 and H4, Mar. Geol., 158, 197-208, 1999.

Stoner, J. S., Channell, J. E. T., Hillaire-Marcel, C., and Kissel, C.: Geomagnetic paleointensity and environmental record from Labrador sea core MD95-2024: Global marine sediment and ice core chronostratigraphy for the last $110 \mathrm{kyr}$, Earth Planet. Sc. Lett., 183, 161-177, 2000.

Svensson, A., Andersen, K. K., Bigler, M., Clausen, H. B., DahlJensen, D., Davies, S. M., Johnsen, S. J., Muscheler, R., Parrenin, F., Rasmussen, S. O., Röthlisberger, R., Seierstad, I., Steffensen, J. P., and Vinther, B. M.: A 60000 year Greenland stratigraphic ice core chronology, Clim. Past, 4, 47-57, doi:10.5194/cp-4-472008, 2008.

Toucanne, S., Zaragosi, S., Bourillet, J. F., Marieu, V., Cremer, M., Kageyama, M., Van Vliet-Lanoé, B., Eynaud, F., Turon, J. L., and Gibbard, P. L.: The first estimation of fleuve manche palaeoriver discharge during the last deglaciation: Evidence for Fennoscandian ice sheet meltwater flow in the English channel ca 20-18 ka ago, Earth Planet. Sc. Lett., 290, 459-473, 2010.

Van Kreveld, S., Sarnthein, M., Erlenkeuser, H., Grootes, P., Jung, S., Nadeau, M. J., Pflaumann, U., and Voelker, A.: Potential links between surging ice sheets, circulation changes, and the Dansgaard-Oeschger cycles in the Irmiger Sea, 60-80 kyr, Paleoceanography, 15, 425-442, 2000.
Versteegh, G. J. M., Blokker, P. K. B., Harding, I., Lewis, J., Oltmanns, S., Rochon, A., and Zonneveld, K. A. F.: Infra red spectroscopy, flash pyrolysis, thermally assisted hydrolysis and methylation (THM) in the presence of tetramethylammonium hydroxide (TMAH) of cultured and sediment-derived Lingulodinium polyedrum (Dinoflagellata) cyst walls, Org. Geochem., 43, 92-102, 2012.

Voelker, A. H. L.: Global distribution of centennial-scale records for marine isotope stage (MIS) 3: a database, Quaternary Sci. Rev., 21, 1185-1212, 2002.

Wagner, G., Beer, J., Laj, C., Kissel, C., Mazarik, J., Muscheler, R., and Synal, H.-A.: Chlorine-36 evidence for the mono lake event in the summit grip ice core, Earth Planet. Sc. Lett., 181, 1-6, 2000.

WOA - World Ocean Atlas: general information available at: http://www.nodc.noaa.gov/OC5/, sampling tool: http://www.geo. uni-bremen.de/geomod/staff/csn/woasample.html (last access: 31 July 2012), 1998.

Wolff, E. W., Chappellaz, J., Blunier, T., Rasmussen, S. O., and Svensson, A.: Millennial-scale variability during the last glacial: The ice core record, Quaternary Sci. Rev., 29, 2828-2838, 2010.

Zaragosi, S., Eynaud, F., Pujol, C., Auffret, G. A., Turon, J. L., and Garlan, T.: Initiation of the European deglaciation as recorded in the north-western Bay of Biscay slope environments (Meriadzek terrace and Trevelyan escarpment): A multi-proxy approach, Earth Planet. Sc. Lett., 188, 493-507, 2001.

Zonneveld, K. A. F., Bockelmann, F., and Holzwarth, U.: Selective preservation of organic-walled dinoflagellate cysts as a tool to quantify past net primary production and bottom water oxygen concentrations, Mar. Geol., 237, 109-126, 2007. 